Clim. Past, 9, 1985-2002, 2013

www.clim-past.net/9/1985/2013/

doi:10.5194/cp-9-1985-2013

(C) Author(s) 2013. CC Attribution 3.0 License.

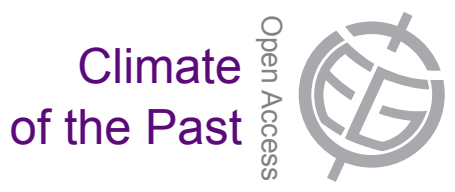

\title{
Droughts in the Czech Lands, 1090-2012 AD
}

\author{
R. Brázdil ${ }^{1,2}$, P. Dobrovolný ${ }^{1,2}$, M. Trnka ${ }^{2,3}$, O. Kotyza ${ }^{4}$, L. Řezníčkováa ${ }^{1,2}$, H. Valášek ${ }^{5}$, P. Zahradníček ${ }^{2,6}$, and \\ P. Štěpánek ${ }^{2,6}$ \\ ${ }^{1}$ Institute of Geography, Masaryk University, Brno, Czech Republic \\ ${ }^{2}$ Global Change Research Centre AV ČR, Brno, Czech Republic \\ ${ }^{3}$ Institute of Agrosystems and Bioclimatology, Mendel University in Brno, Czech Republic \\ ${ }^{4}$ Regional Museum, Litoměřice, Czech Republic \\ ${ }^{5}$ Moravian Land Archives, Brno, Czech Republic \\ ${ }^{6}$ Czech Hydrometeorological Institute, Brno, Czech Republic
}

Correspondence to: R. Brázdil (brazdil@ sci.muni.cz)

Received: 29 April 2013 - Published in Clim. Past Discuss.: 8 May 2013

Revised: 4 July 2013 - Accepted: 8 July 2013 - Published: 20 August 2013

\begin{abstract}
This paper addresses droughts in the Czech Lands in the 1090-2012 AD period, basing its findings on documentary evidence and instrumental records. Various documentary sources were employed for the selection of drought events, which were then interpreted at a monthly level. While the data on droughts before $1500 \mathrm{AD}$ are scarce, the analysis concentrated mainly on droughts after this time. A dry year in 1501-1804 period (i.e. pre-instrumental times) was defined as a calendar year in the course of which dry patterns occurred on at least two consecutive months. Using this definition, 129 dry years were identified (an average of one drought per $2.4 \mathrm{yr}$ ). From the 16th to the 18th centuries these figures become 41, 36 and $49 \mathrm{yr}$ respectively, with the prevailing occurrence of dry months from April to September $(73.7 \%)$. Drought indices - SPEI-1, Z-index and PDSI - calculated for the Czech Lands for April-September describe drought patterns between 1805 and 2012 (the instrumental period). $\mathrm{N}$-year recurrence intervals were calculated for each of the three indices. Using $\mathrm{N} \geq 5 \mathrm{yr}$, SPEI-1 indicates 40 drought years, Z-index $39 \mathrm{yr}$ and PDSI $47 \mathrm{yr}$. SPEI-1 and Z-index recorded $100 \mathrm{yr}$ drought in 1834, 1842, 1868, 1947 and 2003 (50 yr drought in 1992). PDSI as an indicator of long-term drought disclosed two important drought periods: 1863-1874 and 2004-2012. The first period was related to a lack of precipitation, the other may be attributed to recent temperature increases without significant changes in precipitation. Droughts from the pre-instrumental and instrumental period were used to compile a long-term chronology for the Czech Lands. The number of years with drought has fluctu-
\end{abstract}

ated between 26 in 1951-2000 and 16 in 1651-1700. Only nine drought years were recorded between 1641 and 1680, while between 1981 and 2012 the figure was $22 \mathrm{yr}$. A number of past severe droughts are described in detail: in 1540, 1590, 1616, 1718 and 1719. A discussion of the results centres around the uncertainty problem, the spatial variability of droughts, comparison with tree-ring reconstructions from southern Moravia, and the broader central European context.

\section{Introduction}

"Drought" may be defined as a negative deviation of water balance from the climatological normal over a given area. This implies that drought is a result of deficiency in precipitation over an extended period of time, while other meteorological elements (such as temperature, wind and humidity) frequently intensify its impacts. Based on time scales and impacts, droughts may be divided into four categories: meteorological, agricultural, hydrological and socio-economic (Heim, 2002). Meteorological drought is signalled by indicators intrinsic to weather data and precedes the onset of specific impacts, i.e. additional kinds of drought. Agricultural drought may be measured in terms of a duration of weeks to 6-9 months, while hydrological and socio-economic impacts usually became apparent after longer time intervals. Meteorological drought can easily be identified in the instrumental period, while drought events in the pre-instrumental period are usually based on the occurrence of significant

Published by Copernicus Publications on behalf of the European Geosciences Union. 
impacts (e.g. low crop yields, low streams and loss of current in rivers, low still-water levels, and/or socio-economic difficulties). Drought episodes have important consequences for agriculture, forestry, water management and other human activities, as well as for other semi-natural ecosystems.

Droughts in the pre-instrumental period may be studied by derivation from natural proxies and documentary evidence. Information about dry periods can be disclosed by analysis of tree rings wherever their growth relies for the most part on precipitation patterns (Wilson et al., 2005, 2013; Büntgen et al., 2010, 2011b; Cooper et al., 2013). Dry-wet patterns may also appear upon interpretation of other proxies, such as speleothems, pollen content, etc. (e.g. Bradley, 1999). However, only tree rings are currently available for the Czech Lands. For example, fir tree rings from southern Moravia have been used for reconstruction of March-July precipitation totals in the period of 1376-1996 AD (Brázdil et al., 2002) and Z-index for May-June in the 1500-2008 period (Büntgen et al., 2011a).

Documentary evidence is contained within a variety of historical sources that record, incidentally or otherwise, information about weather and related phenomena (Brázdil et al., $2005,2010)$. Weather information of a qualitative nature is interpreted in the form of temperature and precipitation indices, usually on a seven-degree scale from -3 (extremely cold/extremely dry) to +3 (extremely warm/extremely wet). If a series of indices partly overlaps with the period of instrumental measurements, it may be re-calculated to series expressed in terms of degrees Celsius for temperature and millimetres or percentages for precipitation (Dobrovolný et al., 2009, 2010).

Droughts in the period covered by instrumental observations tend to be expressed as various drought indices calculated from a number of meteorological variables. Standardised precipitation index (SPI; McKee et al., 1993), standardised precipitation evapotranspiration index (SPEI; VicenteSerano et al., 2010), Z-index and the Palmer drought severity index (PDSI; Palmer, 1965) are the most commonly employed (see e.g. van der Schrier et al., 2006; Brázdil et al., 2009; Trnka et al., 2009; Dai, 2011; Vicente-Serano et al., 2011). In general, they cover a period for which instrumental records of temperature and precipitation exist in a given country.

After floods, droughts have been the most severe natural disasters in the Czech Republic (Brázdil and Kirchner, 2007), a fact that lends urgency to drought studies from various points of view. The aim of the current paper is to investigate droughts in the Czech Lands for 1090-2012 AD, combining documentary and instrumental data to develop a long-term drought chronology. Section 2 describes the documentary data and drought indices used. Section 3 addresses the methods used in this study. Section 4 discusses the analysis of droughts derived from documentary data and covers drought indices. A chronology of droughts for $512 \mathrm{yr}$ is developed, combining documentary and instrumental data. Five particular years of outstanding past droughts are described. The results obtained are discussed in Sect. 5 and summarised in the final section.

\section{Data}

\subsection{Documentary data}

Information about past droughts can be derived from the various kinds of documentary evidence used as basic data in historical climatology (Pfister, 2001; Brázdil et al., 2005, 2010; de Kraker, 2006; Kiss, 2009; Mauelshagen, 2010) and historical hydrology (Brázdil et al., 2006a, 2012c). Data sources that report droughts in the Czech Lands (for all Czech locations mentioned in this paper see Fig. 1) are mentioned below.

\subsubsection{Annals, chronicles, "books of memory"}

These narrative sources often focus on extreme events (including droughts) in terms of their negative impacts on, or consequences for, human society. The oldest report related to drought speaks of a dry winter in 1090/1091 AD, in which neither snow nor rain fell (Mnich sázavský in Emler, 1874). Next comes a report dated to 1121, when Bohemia suffered severe drought from March to May and all the crops sown dried out (Cosmas in Bretholz, 1923). Further examples, with many weather entries including droughts, may be found in the chronicle of Pavel Mikšovic for the area of Louny, covering the years 1490-1631 (S4), and Bartošek's chronicle for Uherský Brod describing the 1453-1594 period (Zemek, 2004).

\subsubsection{Diaries}

More-or-less systematic qualitative daily weather reports covering the 1693-1783 period (with some gaps) come from diaries kept by the Hradisko Premonstratensian monastery and the Svatý Kopeček priory, both near Olomouc in Moravia (Brázdil et al., 2011). Drought is mentioned there for a total of 17 years. Of primary concern was the most critical period for agriculture (April-September). For example, as reported on 19 September 1750, drought hampered the autumn sowing and prayers for rain were organised on 23 September.

\subsubsection{Tax documents}

Damage to agricultural production related to extreme hydrological and meteorological events constituted grounds for rebate of taxes, a system well-developed in the Czech Lands for the 17th-20th centuries (Brázdil et al., 2006b, 2012b). Documents relevant to the application process are preserved at the level of local, regional and state administration. For example, tax documents in south-eastern Moravia report droughts in 


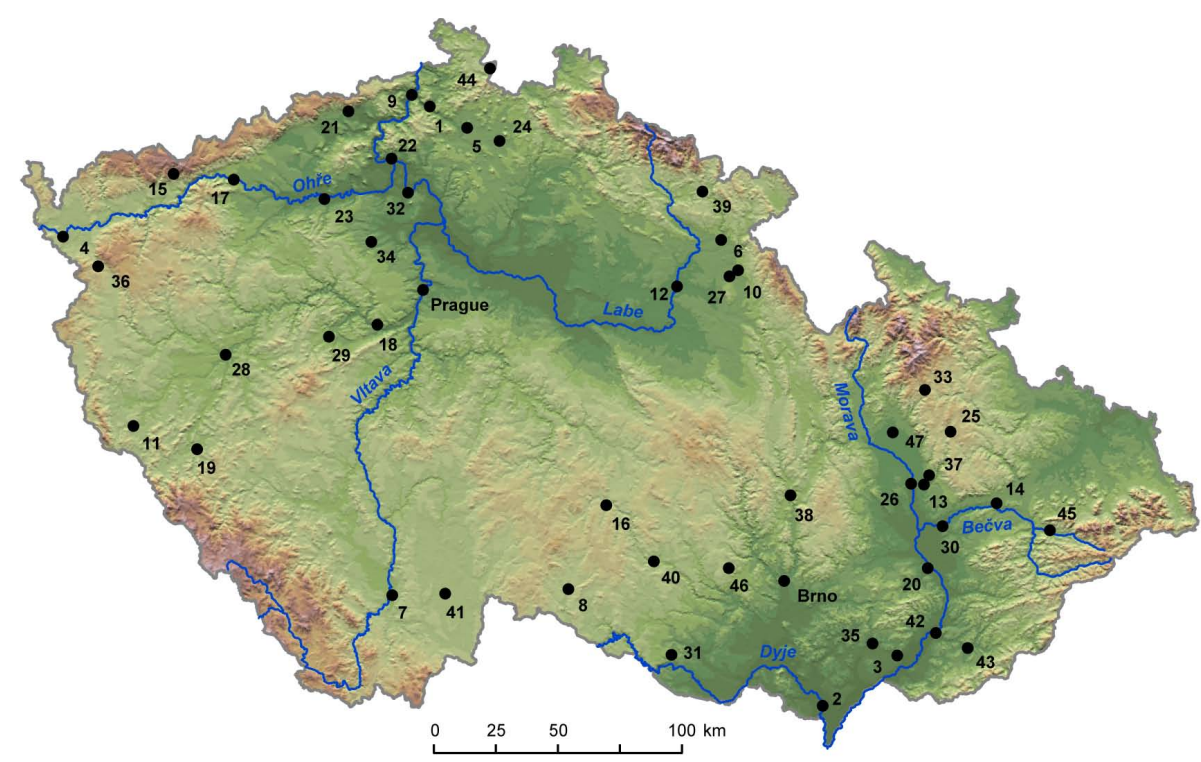

Fig. 1. Locations and rivers in the Czech Republic mentioned in this paper: 1 - Benešov nad Ploučnicí, 2 - Břeclav, 3 - Bzenec, 4 - Cheb, 5 - Česká Lípa, 6 - Česká Skalice, 7 - České Budějovice, 8 - Dačice, 9 - Děčín-Podmokly, 10 - Dobruška, 11 - Domažlice, 12 - Hradec Králové, 13 - Hradisko / Klášterní Hradisko, 14 - Hranice, 15 - Jáchymov, 16 - Jihlava, 17 - Kadaň, 18 - Karlštejn, 19 - Klatovy, 20 Kroměřǐž, 21 - Krupka, 22 - Litoměřice, 23 - Louny, 24 - Mimoň, 25 - Moravský Beroun, 26 - Olomouc, 27 - Opočno, 28 - Plzeň, 29 Praskolesy, 30 - Přerov, 31 - Přímětice, 32 - Roudnice nad Labem, 33 - Rýmařov, 34 - Slaný, 35 - Sobůlky, 36 - Stará Voda, 37 - Svatý Kopeček, 38 - Svitávka, 39 - Trutnov, 40 - Třebíč, 41 - Třeboň, 42 - Uherské Hradiště, 43 - Uherský Brod, 44 - Varnsdorf, 45 - Zašová, 46 - Zbraslav, 47 - Želechovice.

1719, 1834, 1856, 1863, 1869, 1889, 1892, and 1894 (Brázdil et al., 2012b).

\subsubsection{Religious data}

Prayers and supplicatory assemblies for rain were often organised in times of hardship. For example, fasting and prayers for rain were obligatory for the inhabitants of Prague on 15 July 1503 (Staré letopisy české in Palacký, 1941). In a sermon given in Domažlice, Daniel Philomates Senior mentioned that such droughts and lack of water had not been seen as in 1616 for more than a century (S1). On 18 June 1782, the bishop of Brno organised a procession to pray for rain, and when the drought persisted called a seven-hour prayer vigil for all churches on 23 June (Brázdil and Valášek, 2003).

\subsubsection{Letters}

Letters may be of a personal or an official (administrative) character. Petr Uher, an officer at Uherský Brod, wrote an explanatory letter to Commander Albrecht of Waldstein on 3 November 1626 in response to a request that he prepare bread for the army. He spoke of low water and difficulties for water mills arising out of a persistent drought, presenting problems in the collection and milling of grain (Hrubý, 1937). The Cardinal Schrattenbach, in a letter from Olomouc dated 16 August 1719, mentions great heat, lack of water, dried-up grass and a bad harvest, and that he expects that this year (1719) will be as bad as the previous one (1718) (Lechner, 1896).

\subsubsection{Printed sources}

Theatrum Europaeum, a journal on the history of the German-speaking lands by Matthäus Merian, published between 1633 and 1738 in 21 volumes, also provides information about droughts. In 1666, for example, it notes that a hot summer in Austria, Bohemia and Hungary dried out meadows and watercourses and people had to travel six or seven miles for water, while fires broke out in both forests and villages (Theatrum Europaeum, Vol. 10).

\subsubsection{Epigraphic data}

Hydrological droughts may also be commemorated by what are known as "hunger stones". One of these is to be found at the left bank of the River Elbe (Děčín-Podmokly), chiselled with the years of hardship and the initials of authors lost to history (Fig. 2). The basic inscriptions warn of the consequences of drought: Wenn du mich siehst, dann weine ["If you see me, weep.']. It expressed that drought had brought a bad harvest, lack of food, high prices and hunger for poor people. Before 1900, the following droughts are commemorated on the stone: 1417, 1616, 1707, 1746, 1790, 1800, 1811, 1830, 1842, 1868, 1892, and 1893. Similarly, Pfister 


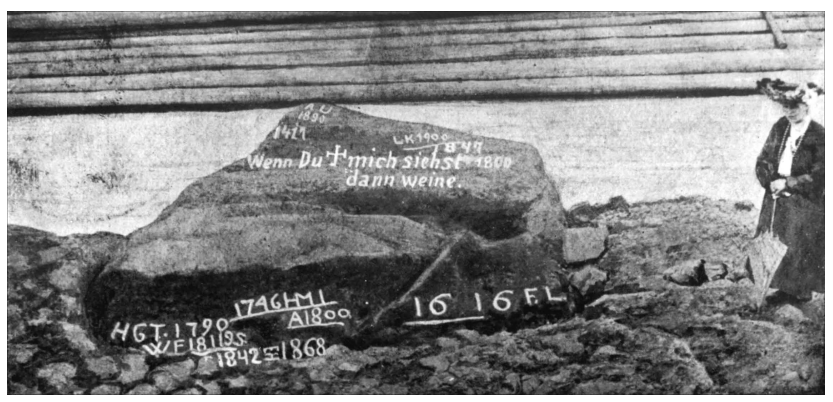

Fig. 2. The "hunger stone" at the left bank of the River Elbe at Děčín-Podmokly (Brázdil and Kotyza, 1995).

et al. (2006) mention low-water marks of the River Rhine on the stone known as "Laufenstein".

\subsubsection{Other sources}

A curious derived example of drought may be encountered in a story about the priest Prokop Diviš, the inventor of the earthed lightning conductor. On 15 June 1754 he erected his "weather instrument" at his parsonage in Přímětice. In autumn 1759 he was approached by villagers, incited by Diviš's opponents, demanding that he remove the apparatus because they considered it a reason for the dry summer that year. Getting no positive response from Diviš, on 19 March 1760 they broke the chains that tethered the instrument and it was thrown down by a thunderstorm the following night. In summer 1760, with thunderstorms doing great damage in fields and vineyards, the villagers asked him to erect his "weather instrument" once more. His response was not positive (Peřinka, 1904).

\subsection{Instrumental data and drought indices}

Brázdil et al. (2012a) calculated mean monthly areal temperature and precipitation series for the instrumental period, using homogenised monthly series from 10 secular stations for temperature and 14 stations for precipitation. These series were confronted with areal temperature and precipitation means for the Czech Republic in the 1961-2000 period, for which the station coverage is at its best. Based on this comparison, each of the 10 (temperature) and 14 (precipitation) series was corrected to establish areal means for the 19612000 period. The median value of corrected station data was considered as the final mean areal series for the Czech Lands. This series may be partly biased by the number of stations available for use. Series for all stations were available only from 1883 onwards for temperature and from 1876 for precipitation (see Sect. 5.1.2).

Of the various drought indices available, the one-month standardised precipitation-evaporation index (SPEI-1) and the Palmer Z-index, representing short-term or mediumterm drought, and the Palmer drought severity index (PDSI) as characteristic of long-term drought, were established by calculation from these Czech temperature and precipitation series (Brázdil et al., 2012a).

The SPEI is based on the monthly difference between precipitation and potential evapotranspiration (PET), thus representing a simple climatic water balance. The authors followed the procedure established by Vicente-Serano et al. (2010) based on the Thornthwaite (1948) method requiring only data on mean monthly temperature. With a value for PET, the difference between precipitation and PET for any given month may be calculated, which provides a simple measure of the water surplus or deficit for the month analysed. The average value of SPEI is zero and the standard deviation is one. An SPEI of zero indicates a value corresponding to $50 \%$ of the cumulative probability of a precipitation and PET difference, according to a log-logistic distribution.

The PDSI (Palmer, 1965) is based on a supply-anddemand concept of the water balance equation and thus incorporates antecedent precipitation, moisture supply, and demand at the surface as calculated according to the Thornthwaite (1948) PET method. It applies a two-layer, bucket-type model for soil moisture computations with three assumptions relating to the soil profile characteristics:

i. the water-holding capacity of the surface layer is set at a maximum of $25 \mathrm{~mm}$;

ii. the water-holding capacity of the underlying layer has a maximum value dependent on the soil type;

iii. water transfer into or out of the lower layer only occurs when the surface layer is full or empty.

The method of PDSI calculation includes an intermediate term known as the Palmer moisture anomaly index or Z-index, which is a measure of surface moisture anomaly for a given month without consideration of the antecedent conditions that are intrinsic to PDSI. It is basically moisture departure, adjusted by a weighting factor known as the "climatic characteristic". Compared to PDSI, the Z-index may be used to track drought events on a monthly basis as it responds relatively quickly to changes in soil moisture and is able to rank the dryness or wetness of individual months.

\section{Methods}

Certain basic methodological allowances must be made in the interpretation of droughts from documentary evidence. It follows from Sect. 2.1 that many documentary sources mention drought directly. Sometimes this information is complemented by impacts that express the severity of this event: bad yields of crops (mainly cereals, vegetables and fruit), shortage of water, low level of water/loss of flow in rivers, watercourses drying up, rivers that can be crossed on foot or by some conveyance, water mills that cannot mill, a dearth of 
meal and bread, a further period without rain, hampered autumn sowing, processions of religious entreaty and prayers or fasts for rain, and so on.

Dating a drought may also present problems (all dates in this paper are re-calculated to the Gregorian calendar). Some reports mention the period without rain directly, indicating meteorological drought. For example, in 1540 Pavel Mikšovic of Louny recorded that there was no rain from 26 May to 8 August and a general state of drought continued until 14 October (S4). The majority of reports specify drought duration to the level of a number of months, or seasons. For 1630, the tanner master Michel Stüeler mentioned a dry summer and autumn when all the brooks and springs went dry in Krupka. He considered this drought more severe than those in 1590 (S6). Several sources record drought only for a given year without exact specification of the time of that year. An example may be found in Michel Stüeler's summary for 1635: "a dry year, little grain and fruit, good wine" (S6).

The spatial pattern of droughts interpreted from documentary evidence is related to the Czech Lands as a whole. This is supported by the fact that individual drought episodes are captured by documents from a variety of places and regions scattered throughout the territory of the Czech Lands in the majority of cases. Moreover, in some cases particular drought events are directly reported for far larger territorial units, such as Bohemia or Moravia. Such data coverage is important for comparison with droughts in the instrumental period, in which drought indices are derived for the entire Czech territory.

Our interpretation of dry conditions/droughts was done at a resolution of months. For the purposes of this paper, a drought is considered acceptable in calculations only if it lasts for two consecutive months. Years that do not fulfil this requirement were omitted and not included for further use. For example, the year 1725, although it was dry in February, April and October, was not considered because of none of the months followed one another.

In order to express the intensity of past droughts as derived from documentary evidence, selected months in a given dry year are classified by precipitation indices on the sevendegree scale used in historical-climatological studies (see e.g. Pfister, 1999; Glaser, 2008). Dry months are described as: -1 dry, -2 very dry, -3 extremely dry.

The extremeness of droughts as characterised by SPEI-1, Z-index and PDSI was expressed via calculation of the return period for average $\mathrm{N}$-year recurrence intervals $(N=2$, $5,10,20,50$ and $100 \mathrm{yr}$ ) of the corresponding index. First, values of drought indices were modelled with Gaussian normal distribution and the suitability of this theoretical distribution was tried with goodness-of-fit tests. Then probability of occurrence $(p)$ was estimated from the frequency distribution of Gaussian distribution. Finally, return periods $(N)$ were derived as an inverse of probability estimates, that is $N=1 / p$.

\section{Results}

\subsection{Droughts in the Czech Lands based on documentary data}

\subsubsection{Droughts before 1500 AD}

Information about dry episodes and droughts before $1500 \mathrm{AD}$ is largely confined to Bohemia, reflecting the better availability of ancient documents in the part of the kingdom closest to the capital (Brázdil and Kotyza, 1995). However, the eastern part of the Czech Lands, i.e. Moravia, is also mentioned in some cases. An overview with basic descriptions appears in Table 1. Of the credible reports, only the first speaks of dryness in winter (DJF) while in all other cases drought occurred in spring (MAM), summer (JJA) or in the whole summer half-year, when the consequences of such events were at their most severe, significantly influencing harvests. The number of droughts (total 36 cases) in individual centuries also reflects the availability of existing documentary sources: four cases in the 12th century, five in the 13 th century, 14 in the 14 th century, and 13 cases in the 15th century.

\subsubsection{Droughts after $1500 \mathrm{AD}$}

Figure 3 shows a chronology of droughts in the Czech Lands during the 1501-1804 period, based on documentary data. It follows that documentary evidence discloses dry patterns at all times of the year. A total of $49 \mathrm{yr}$ with dry patterns/droughts emerged in the 18th century, followed by the 16th century with $41 \mathrm{yr}$ and the 17 th century with $36 \mathrm{yr}$. The highest number of years with droughts, seven per decade, occurred in 1701-1710 (Fig. 4a). Six droughts per decade were recorded in 1511-1520, 1531-1540, 1631-1640, 1721-1730 and 1781-1790. Only two years with drought occurred in 1521-1530, 1641-1650, 1661-1670 and 1671-1680. In the 18th century three dry years were recorded between 1711 and 1720. The longest series of consecutive years with drought occurred in the 18th century: seven years in 1778-1784, with five years in 1704-1708 and 1724-1728 in second place.

Despite dry months recorded outside the summer half-year (April-September), droughts prevail in this period: 16th century -135 months out of 160 (i.e. $84.4 \%$; maximum June $18.1 \%$ ); 17 th century -99 of 139 (i.e. $71.2 \%$; maximum May $15.1 \%$ ); from 1701 to 1804 there were 136 out of 206 (i.e. $66.0 \%$; maximum August $13.1 \%$ ). In the winter halfyear (October-March), droughts were more frequent in October (between $9.4 \%$ in the 17 th century and $6.9 \%$ in the 16th century). Decadal frequencies of dry months are shown in Fig. 4b. The highest numbers of dry months appeared in 1511-1520, 1701-1710 and 1721-1730 (29 months each) followed by 1531-1540 (26). The lowest numbers of dry years were recorded for 1521-1530 and 1641-1650 (only six months each). 

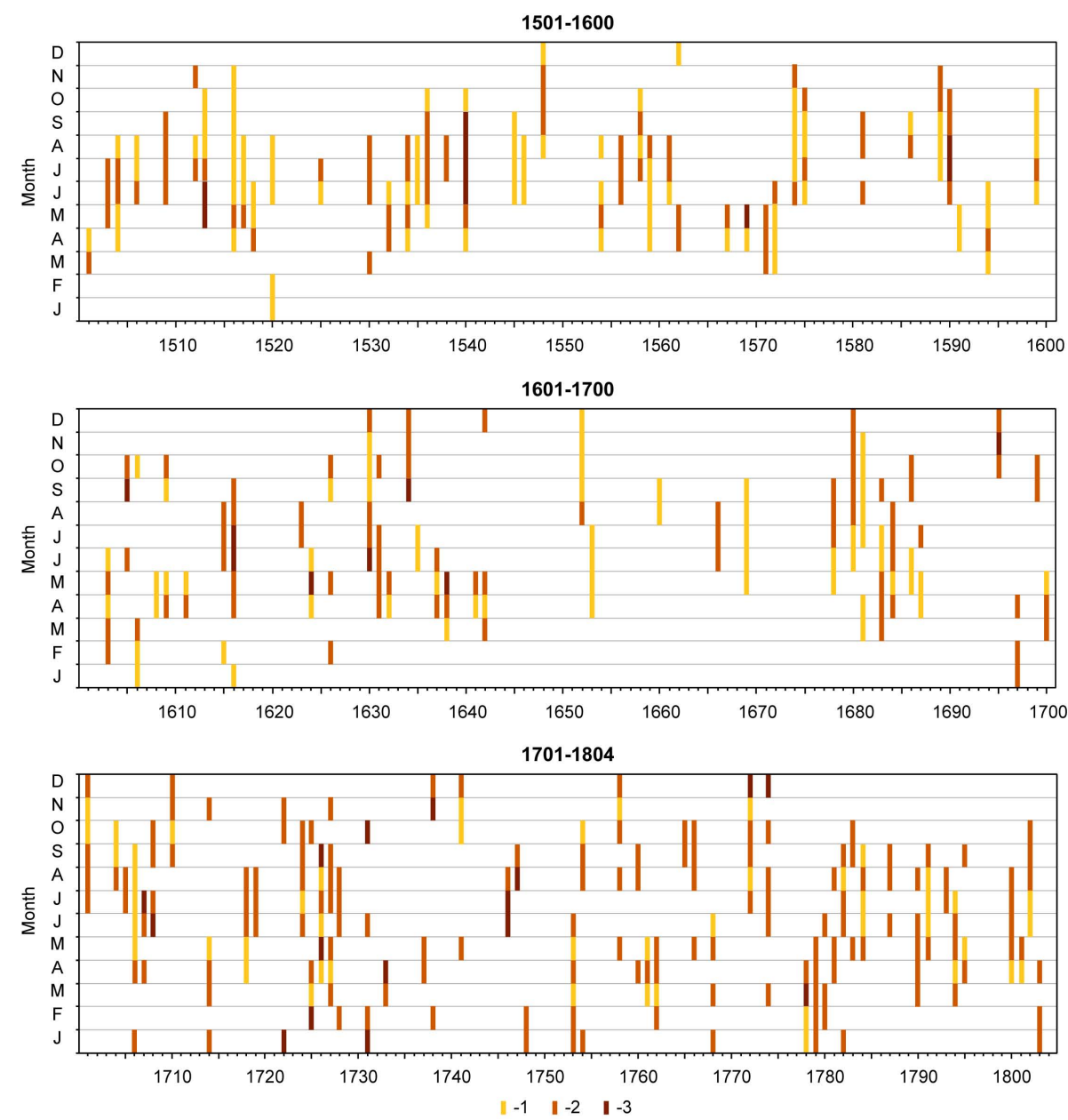

Fig. 3. Dry months/droughts in the Czech Lands interpreted from documentary evidence for the 1501-1804 period, with expression of their intensity by precipitation indices: -1 dry month, -2 very dry month, -3 extremely dry month.

As follows from the previous data, a total of $129 \mathrm{yr}$ with dry months/droughts were identified in the 1501-1804 period, giving an average of one drought per $2.4 \mathrm{yr}$ in the Czech Lands. Of a total of 505 dry months, $372(73.7 \%)$ occurred in the summer half-year, from April to September (maximum in June and August $13.5 \%$ each), and 133 (26.3\%) in the winter half-year, from October to March (maximum in October $7.9 \%)$

The intensity of past droughts is described in terms of precipitation indices in Fig. 3 and summed for the corresponding years in the decade in Fig. 4c (higher negative sum of indices means deeper drought). In general, this follows the decadal distributions of frequency of dry years or dry months within them. However, it is remarkable that lower-frequency droughts occurred in 1721-1730 in contrast with the most frequent in 1701-1710, which were also the most intensive. Despite the higher number of drought months in 1511-1520, their intensity was lower than in 1531-1540.

\subsection{Droughts in the Czech Lands in the instrumental period}

Because, for the greater part, dry months/droughts occur from April to September, the drought indices employed also span this summer half-year. This analysis of droughts in the Czech Lands in the instrumental period is based on SPEI-1, Z-index and PDSI values calculated from homogenised monthly series of mean areal Czech temperature and precipitation series for the 1805-2012 period (Brázdil et al., 2012a). From SPEI-1, Z-index and PDSI April-September series, values of $\mathrm{N}$-year recurrence intervals $(N=2,5,10$, $20,50,100)$ were calculated. An overview of such indices at a recurrence interval of $N \geq 5 \mathrm{yr}$ appears in Fig. 5. The $5 \mathrm{yr}$ return period was based on agro-climatological studies (e.g. Hlavinka et al., 2009; Trnka et al., 2012) showing harvests significantly influenced by drought in approximately $20 \%$ of cases over the past $130 \mathrm{yr}$.

Figure 6 shows the decadal frequencies of droughts expressed by SPEI-1, Z-index and PDSI for April-September 
Table 1. Dry weather and droughts in the Czech Lands before 1500 AD (Brázdil and Kotyza, 1995): Bo - Bohemia, BP - Benešov nad Ploučnicí, HK - Hradec Králové, Ka - Karlštejn, Kd - Kadaň, Mi - Mimoň, Mo - Moravia, Pr - Prague, Tř - Třeboň, Va - Varnsdorf, Zb Zbraslav.

\begin{tabular}{|c|c|c|c|}
\hline Year & Months & Place & Description \\
\hline 1090/91 & DJF & Pr, Bo, Mo & No rain or snow \\
\hline 1121 & MAM & Pr, Bo & Crops dried out \\
\hline 1128 & JJA & Pr, Bo & No details \\
\hline 1177 & JJA & Pr, Bo & Poor crop \\
\hline 1194 & JJA & Pr, Bo & Poor crop, high prices \\
\hline 1252 & MAM & Pr, Bo & Rainy at the end of spring. Spring crops perished. \\
\hline 1260 & JJA & Pr, Bo & No details \\
\hline 1262 & MAM-JJA & Pr, Bo & Autumn and spring crops perished, grass dried up, poor harvest of fruit and wine \\
\hline 1266 & JJA & Pr, Bo & Poor harvest of cereals, fruit and wine \\
\hline 1283 & MAM & Pr, Bo & No details \\
\hline 1307 & MAM-JJA & $\mathrm{Zb}, \mathrm{Bo}, \mathrm{Mo}$ & Poor harvest, famine \\
\hline 1312 & JJA & $\mathrm{Zb}, \mathrm{Bo}, \mathrm{Mo}$ & Poor harvest, high prices, famine \\
\hline 1315 & before 2 Aug & $\mathrm{Zb}, \mathrm{Bo}$ & Poor harvest \\
\hline 1326 & JJA & $\mathrm{Zb}, \mathrm{Bo}$ & Complete loss of spring crops \\
\hline 1328 & before 13 Aug & south Mo & No details \\
\hline 1333 & JJA (after 22 May) & $\mathrm{Zb}, \mathrm{Bo}$ & Poor harvest of summer cereals, yield of wine low \\
\hline 1334 & JJA & $\mathrm{Zb}, \mathrm{Bo}$ & No details \\
\hline 1337 & until Jul & $\mathrm{Zb}, \mathrm{Bo}$ & Poor harvest of cereals and wine, high prices \\
\hline 1348 & JJA & Pr, Bo & Land dried out, poor cereal crop \\
\hline 1352 & after 8 May & Pr, Bo & Poor harvest of cereals and other crops \\
\hline 1368 & from April & Pr, Bo & Bad harvest of spring crops \\
\hline 1369 & $(\mathrm{JAS} ?)^{1}$ & Bo & Better wine in Bohemia than in Austria due to severe drought \\
\hline 1371 & before 18 May & Pr, Bo & Frequent fires \\
\hline 1393 & JJA & Pr, central Bo & Possible to cross the River Vltava on its bed, water "as green as grass" \\
\hline 1423 & JJA & Pr, BP, Bo & No details \\
\hline 1425 & JJA & Pr, Bo & No details \\
\hline 1432 & 2 May-27 Jul & Ka, Bo & Rained only once, lightly, during this period \\
\hline 1441 & 2 Apr-2 Aug & Ka, Bo & Bad harvests of hay, cereals and peas \\
\hline 1442 & JJA & Pr, Bo, HK & Poor harvest of cereals and hay, severe shortage of water \\
\hline 1461 & JJA & $\mathrm{Mi}, \mathrm{Va}$ & No details \\
\hline 1469 & May-Sep & $\mathrm{Kd}$ & Erroneously dated to 1468 \\
\hline 1471 & JJA & $\mathrm{Mi}, \mathrm{Va}$ & Rivers dried up \\
\hline 1473 & JJA & Pr, HK, Ka, BP, Bo & Streams dried up. Forest fires. Poor harvest of cereals and other crops. \\
\hline 1476 & MAM & Tr̆, south Bo & Shortage of water \\
\hline 1480 & JJA & Bo & No details \\
\hline 1482 & JJA & $\operatorname{Pr}$ & Water of the River Vltava green and stinking. Shortages. \\
\hline
\end{tabular}

at a recurrence interval of $N \geq 5 \mathrm{yr}$ during the 1805-2012 period. Comparison of frequencies of SPEI-1 and Z-index revealed only very small differences between them. The highest number of $N \geq 5 \mathrm{yr}$ droughts occurred in 2001-2012 (seven), followed by 1991-2000 and 1861-1870 (five each). No such case for either index was recorded in 1881-1890 and 1951-1960 (for Z-index in 1871-1880 and 1931-1940 as well). The years in which centennial droughts were achieved for both indices were 1834, 1842, 1868, 1947 and 2003. A $50 \mathrm{yr}$ drought was recorded in 1992. SPEI-1 and Z-index both show similar distribution over particular centuries: 19th century -45.0 and $48.7 \%$; 20th century -37.5 and $38.5 \%$ (2001-2012 - 17.5 and 12.8\%). Based on Z-index, drought events in the early 21 st century are approximately 2.1 times more likely than in the 19th century and 2.8 times more likely than during the 20th century.

At least one drought with PDSI $\geq$ PDSI $_{5}$ per decade was recorded in the periods $1805-1880,1931-1960$ and 19712012. Seven droughts in the 2001-2010 decade (PDSI 50 for 2009 and PDSI $_{100}$ for 2007) were followed by six cases in 1861-1870 ( PDSI $_{50}$ for 1866) and five in 1991-2000 (Fig. 6). These three decades cover a total of $38.3 \%$ of the 47 droughts identified. On the other hand, no droughts occurred in 1881-1930 and 1961-1970. Twenty-one droughts $(44.7 \%)$ were recorded in the 19th century, $17(36.2 \%)$ in the 20th century and nine (19.1\%) afterwards. Two drought sequences stand out in particular: 1863-1874 (interrupted in 1867; in 1868, $\mathrm{PDSI}_{2}$ ), and 2004-2012. While the first case 

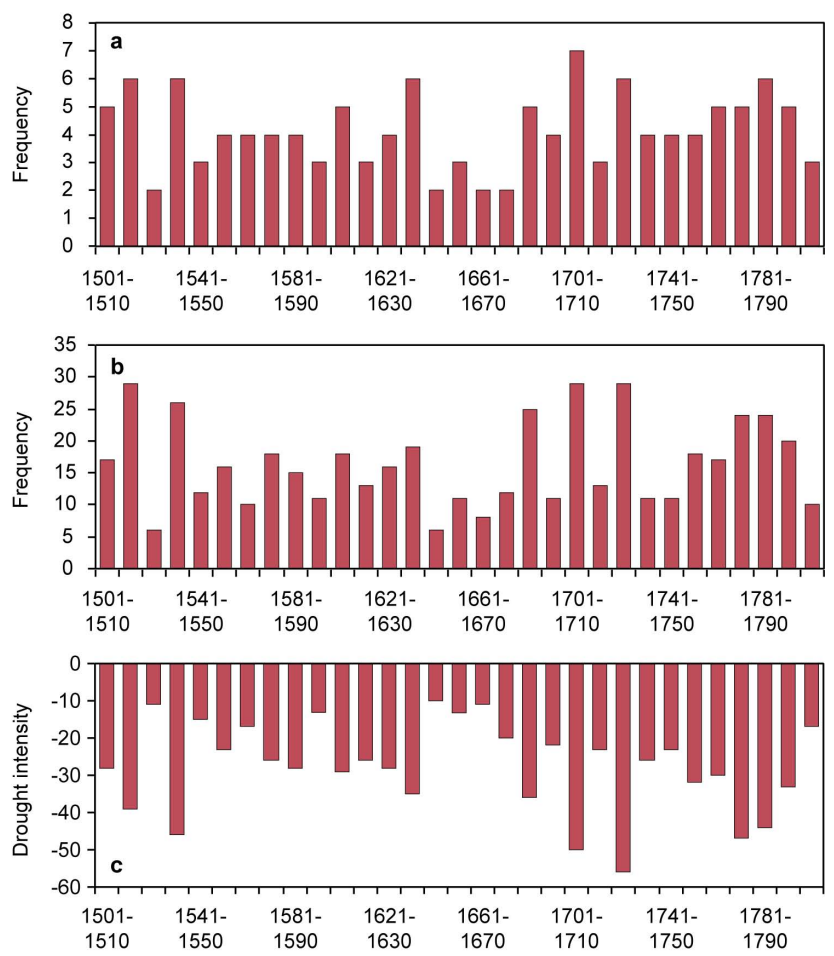

Fig. 4. Decadal frequencies of droughts in the Czech Lands in the 1501-1804 period: (a) years with drought, (b) dry months in drought years, (c) drought intensity.

reflects mainly a lack of precipitation in a cooler climate, the second may be attributed in greater part to increasing temperatures, mainly in JJA, also in MAM (Brázdil et al., 2012a).

\subsection{Long-term chronology of droughts in the Czech Lands}

The compilation of a long-term Czech drought chronology is complicated by the two different sources from which drought data are derived. Documentary evidence facilitates disclosure of the frequency of droughts, with identification of corresponding months and the dry patterns that prevail from April to September. From the character of these data it follows that they have to be compared with instrumental data for the same months. Moreover, droughts derived from documentary data express quite short-term or medium-term droughts, favouring indices such as SPEI-1 and Z-index over PDSI, an indicator of long-term drought. Examples may be cited: a PDSI 50 in 1835 reflected drought from the previous year 1834 (SPEI- $1_{100}$, Z-index ${ }_{100}$ ), while PDSI 100 in 2007 and PDSI $_{50}$ in 2009 were the cumulative effects of droughts in the 2000s. This is why droughts in the 1805-2012 period were selected primarily on a basis of concurrent occurrence of SPEI- 1 and Z-index at $N \geq 2 \mathrm{yr}$.

Figure 7 shows the decadal frequency of droughts in the Czech Lands during the 1501-2012 period. Droughts before
$1500 \mathrm{AD}$ were not used in the compilation of this chronology; the patchy nature of available documentary sources renders them too incomplete. The series compiled shows quite consistent patterns throughout the period. Comparable numbers of years with drought are typical of the 18th-20th centuries: 49, 47, and 47 . Only 36 cases were recorded in the 17 th century (16th century -41 ). If matters are addressed in $50 \mathrm{yr}$ periods, the highest number of years with drought is established for 1951-2000 (26), followed by 1751-1800 (25), 1701-1750 and 1801-1850 (24 each), 1851-1900 (23) and 1501-1550 (22). The lowest numbers were recorded in 1651-1700 (16) and 1551-1600 (19). At the decadal level, the driest patterns occurred in 1801-1810 with eight years (of which three were derived from documentary data). Seven dry years per decade occurred in 1701-1710, 1861-1870, 19411950, 1991-2000 and 2001-2010. Only two droughts per decade were derived for 1521-1530, 1641-1650, 1661-1670 and 1671-1680. Four drought years per decade occurred 17 times, the most often. The longest continuous drought periods lasted for seven years in 1778-1784, 1988-1994 and 2003-2009.

\subsection{Selected outstanding drought events in the Czech Lands in the pre-instrumental period}

Five cases of outstanding droughts in the pre-instrumental period appear here to demonstrate description based on documentary evidence. While the droughts in 1540, 1590 and 1616 are documented prevailingly by sources from Bohemia, 1718 and 1719 were selected as two consecutive very dry years with most of their documentary data from Moravia.

\subsubsection{The year 1540}

Summer 1540 was hot and dry. Water was short and forest fires broke out (S2; S4; Dudík, 1858; d'Elvert, 1861; Palme, 1913; Kolár, 1987). A dry period is mentioned for the surroundings of the town of Jihlava, lasting from 6 April until the end of the year and resulting in a bad yield of both green vegetables and root crops (d'Elvert, 1861). A very dry and warm period, with an acute shortage of grain and vegetables, is noted for around Uherský Brod around the same time (Zemek, 2004). Pavel Mikšovic (S4) notes a hot and dry period for Louny, 26 May-13 October, with rain only on 8 August and warm weather lasting until the very end of the year. Pankraz Engelhart (Gradl, 1884), speaking of Cheb, records a dry year, with sowing and field-work extended right to the end of the year. Andreas Baier (Gradl, 1884) mentions a dry summer there, and warm weather until the end of the year. In the 1450-1622 period, warm and dry weather led to the earliest start to harvest recorded in the Louny region, and mention is made of early starts and ends to harvesting barley, oats and peas (Brázdil and Kotyza, 2000). Reports also speak of a poor or medium harvest of grain (S2; Gradl, 1884; Kolár, 1987). The year of 1540 was exceptionally hot 


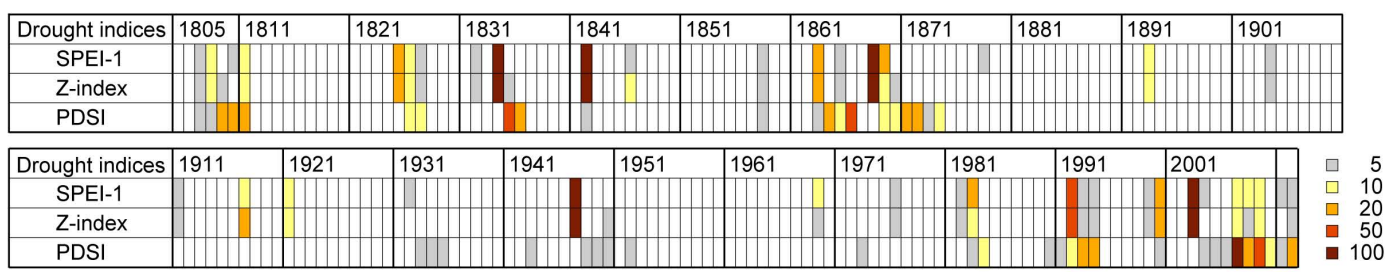

Fig. 5. Droughts expressed by SPEI-1, Z-index and PDSI for April-September with their recurrence interval $N \geq 5 \mathrm{yr}$ in the Czech Lands during the 1805-2012 period.
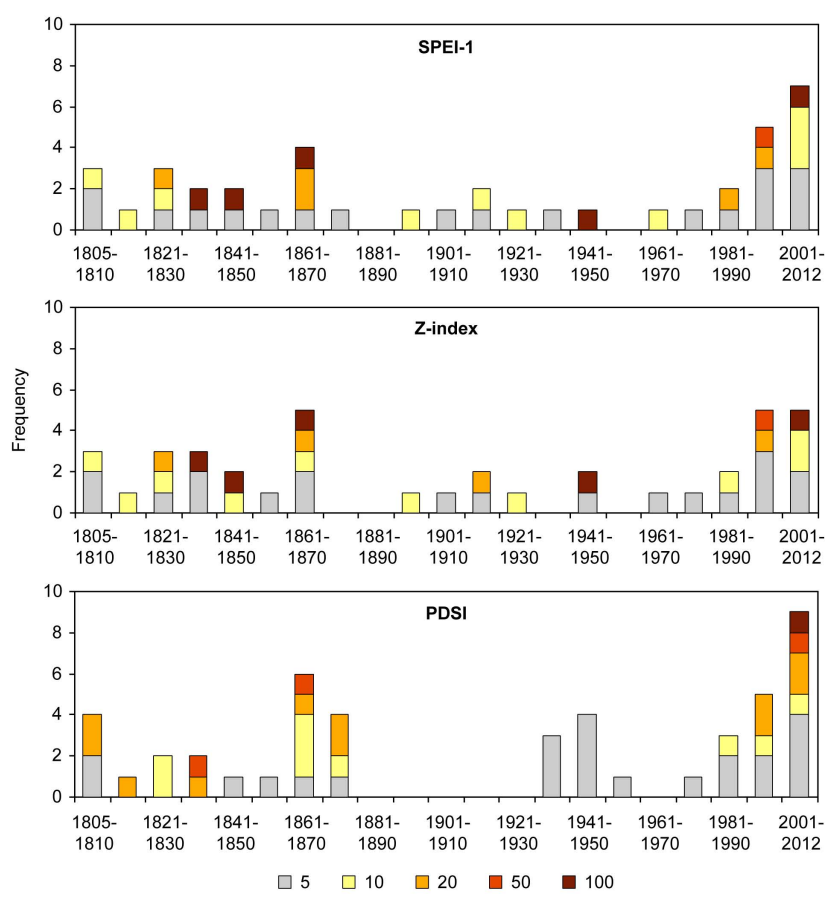

Fig. 6. Decadal frequencies of droughts expressed by SPEI-1, Z-index and PDSI for April-September in order of their N-year recurrence interval $(N=5,10,20,50,100)$ for the Czech Lands in the 1805-2012 period.

in Europe, comparable with the outstanding event of summer 2003 (Wetter and Pfister, 2013); it was also extremely dry on the broader European scale (Wetter et al., 2013).

\subsubsection{The year 1590}

Summer 1590 was hot and dry. Thus, "great drought" is reported for Olomouc around 25 July, when mills had insufficient water to function (Dudík, 1858). Heat, drought, a dry summer and frequent fires appear in reports from České Budějovice (Mareš, 1922), Jáchymov (Wolkan, 1890) and Plzeň (Strnad, 1883). Simon Hüttel of Trutnov speaks of a hot, dry summer, and mentions that there had been no rain for a long time (Schlesinger, 1881). Further sources also specify the length of the period without rain (3 June-10 September in Slaný - Peters, 1898; raining only two or three times between
10 June and 21 September in Litoměřice - S5; 17 June-6 August in Dobruška - Šủla, 1967). They also record streams drying up, mills idle, low water level in the Rivers Vltava, Elbe and the Ohře, green water (algae proliferating in low flow conditions) and poor harvests (S3; S4; Dvorský, 1972). Marek Bydžovský of Florentinum (Kolár, 1987) in Prague notes fruit yields and the harvest in general were poor, while the chronicler for Trutnov records poor yields of vegetables and fruit (Schlesinger, 1881). The chronicler for Dobruška speaks of a poor harvest for summer products but an abundance of winter crops (Šula, 1967). A poor harvest resulted in severe shortages (S4; Gradl, 1884; Peters, 1898; Indra and Turek, 1946) and grain had to be imported from Silesia to Trutnov and its surroundings (Schlesinger, 1881). However, perhaps some consolation lay in a good yield of excellent wine (S5; Ondrůj, 1977). Further sources, incidental to records of an earthquake on 15 September, speak of heat, drought and brooks drying up before it occurred (Strnadel, 1950; Kolár, 1987). At Cheb it became impossible to mill grain due to the low level of water from summer onwards, although the lowest water on the River Ohře after the following dry autumn was recorded as late as 20 December (Gradl, 1884). The soil dried out to dust in autumn, which made sowing difficult (S5). Autumn rain is mentioned for only 28-29 October (S5; Peters, 1898). Varnsdorf had no rain for 38 weeks; the grass withered in the intense heat and there were losses of fish and game (Palme, 1913). Hans Kriesche, speaking of Česká Lípa, mentions that the year was entirely dry, with no rain all summer and winter; milling became impossible and severe shortages followed (S3). A very hot and dry summer was also reported in Austria (Klemm, 1983; Lauscher, 1985), Germany (Glaser, 2008), Silesia and Poland (Rojecki et al., 1965) or Switzerland (Pfister, 1999).

\subsubsection{The year 1616}

Hay-making and the harvests of barley, rye, oats and wheat started very early in the Louny region. The end of the harvest was even earlier than that of the 1517-1622 period (Brázdil and Kotyza, 2000). This was due to extraordinary drought, starting as early as April (S4; Palme, 1913) and continuing throughout the summer (S3; Feifalik, 1859; Wolkan, 1890; Richter, 1940; Indra and Turek, 1946). Daniel Basilius of Deutschenperk mentions great heat, dried-up rivers and the 


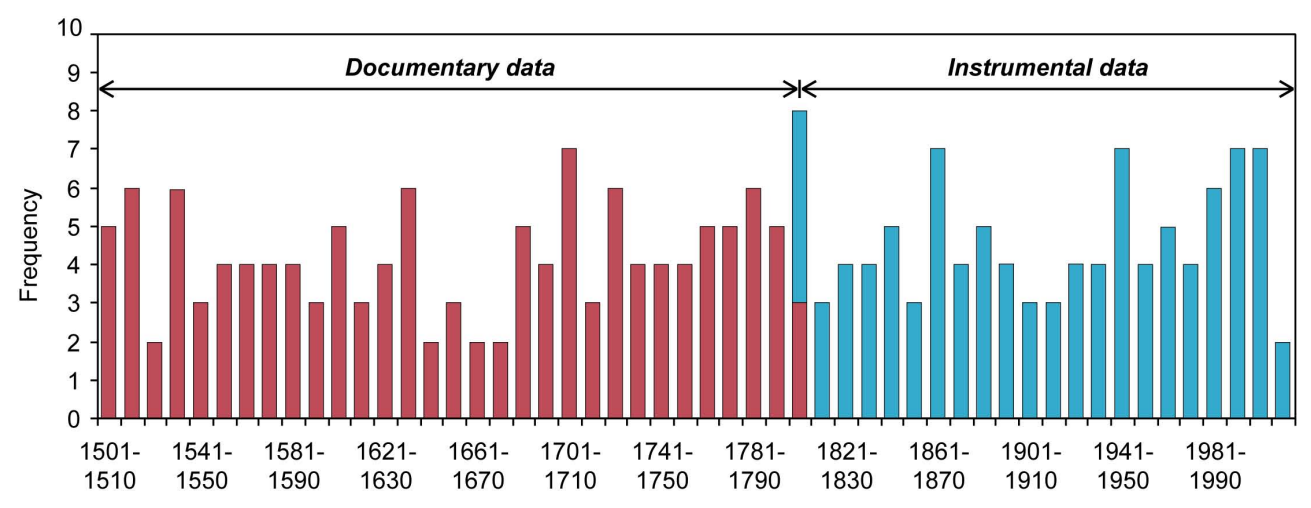

Fig. 7. Decadal frequencies of droughts in the Czech Lands in the 1501-2012 period compiled from documentary data (1501-1804) and the instrumental record (1805-2012).

River Vltava in Prague "stinking" (Winter, 1899). Daniel Philomates Senior, in a sermon at Domažlice, referred to the "drought of the century" (S1). The exceptionally dry year of 1616 is also recorded with a mark on a "hunger stone" on the River Elbe (Fig. 2). Pavel Mikšovic (S4) mentions an average harvest of winter grain in Louny, although spring cereals and other earlier field crops withered. Very dry weather dried out the grass and the aftermath was not mown at all. Switzerland had much the same kind of weather (Pfister, 1999), as did Germany (Glaser, 2008).

\subsubsection{The year 1718}

Eight weeks without rain was noted in Česká Skalice (Schreiber, 1909). A report from Klatovy mentions severe drought, in which some fish cultivation ponds dried out and the fry perished (Peters, 1946; the same for 1719). Drought led to a lack of water in Opočno (Č́žžek, s.a.). In Uherské Hradiště, severe drought before 24 June marred the growth of spring grain and also dried it out (Fišer, 1920). A record from Klášterní Hradisko Monastery dated 11 June speaks of "great drought" (Brázdil et al., 2011). The summer was dry in Rýmařov and one had to go 5-6 miles to get milling done (Tutsch, 1914). The River Dyje dried out around Břeclav (Dostál et al., 1968). Severe drought and financial hardship are described in a letter of 10 September from Olomouc (Lechner, 1896). A source from Moravský Beroun describes drought, small quantities of grain and subsequent shortages, with the River Bečva drying up near Přerov and mills at a standstill around Kroměřǐz (Berger, 1901). Unusual drought is recorded at Bzenec (Cvrček, 1903). The Piarist diary from Stará Voda mentions the year 1718 as memorable for drought, with only five hard rains after spring and the ground cracked (S8). Severe drought, desiccated grain, bad harvest, shortages and a lack of water for mills are mentioned by sources for Svitávka, Sobůlky, Třebíč, Zašová and Želechovice (Brázdil and Kirchner, 2007).

\subsubsection{The year 1719}

A report from Roudnice nad Labem indicates that people were forced by the hardship of drought to pick the spring grain by hand (S7). Jan Josef Čížek from Opočno reported that 1719 was even worse than 1718 - mills could not mill for many weeks, the harvest was very bad and there was a lack of fodder (Č́žzek, s.a.). At Moravský Beroun, due to great heat and drought, one had to go six miles or more to get milling done. There was no grain or flax, pastures dried out and the cabbages were eaten by caterpillars (Berger, 1901). A letter of 16 August from Olomouc mentions great heat, lack of water, dried-up grass and a bad harvest (Lechner, 1896). In Uherské Hradiště on 28-30 August people took to the streets in procession to beseech God for rain because of great drought and lack of water in mills (Fišer, 1920). In Bzenec, the water reservoir dried up (Cvrček, 1903). In Hranice it was possible to cross the River Bečva on its bed (Indra, 1929-1930). At Praskolesy, due to drought from 4 June onwards, there was a bad harvest of grain and flax (Tiray, 1907). Further great drought, desiccated grain and a bad harvest are mentioned from Svitávka, severe drought for Třebíč, severe drought and little water for mills at Zašová, severe drought and shortages for Želechovice (Brázdil and Kirchner, 2007).

Dry and warm patterns in 1718 and 1719 in the Czech Lands are confirmed by data from Switzerland (Pfister, 1999), Austria (Strömmer, 2003) and Germany (Glaser, 2008).

\section{Discussion}

\subsection{Chronology of droughts in the Czech Lands and associated uncertainties}

The results obtained for this paper are partly biased by a number of uncertainties related to documentary data and the spatial variability of precipitation. 


\subsubsection{Uncertainty in documentary data}

The density and availability of documentary sources bear in very important fashion upon the detection of droughts and all analyses that arise out of historical sources. Limitations follow from the number of records preserved and excerpted, their territorial distribution, and other intrinsic factors. Variations in economic, social and political circumstances are reflected in significant fluctuations in the density of records, i.e. some periods are rich in data while others are poorer, or records are simply absent. This means that the number of years with dry months/droughts in individual centuries may express availability of documentary evidence rather than real past situations. For example, while the highest density of information relates to the 18 th century, the 17 th century is characterised by a lower number of available sources. The Czech Lands were devastated in the wake of the Thirty Years' War (1618-1648) and in the four decades of 1641 to 1680 only nine years with drought were documented.

A further problem for the interpretation of drought arises out of the great spatial variability of the documentary data, which then has to be generalised for the entire Czech Lands. For example, in the 16th century, the number of sources from Bohemia (mainly its north-western part) is much higher than that from Moravia. Care has also to be taken in the interpretation of the duration of a given drought, often attributed in documentary sources to just a season of the year (e.g. to MAM or JJA) or to the year as a whole. Statements of the "dry summer, dry spring" type do not necessarily mean that all the months concerned were truly dry.

In this study, the distribution of dry months through the year is partly influenced by the availability of documentary sources. From the 16th to the 18th century, there is a considerable decline in the relative number of dry months from April to September with respect to the total number of dry months. This may be related to the fact that, in addition to standard narrative sources that concentrate largely upon the weather during the vegetation period, other descriptions of the weather, taking in the whole year (e.g. weather diaries), started to appear in growing numbers for later times. They then come to be used in greater measure for interpretation. By the 18th century, this trend is already becoming reflected in a relative increase of the number of dry months in the total disclosed between October and March and a relative decrease in those between April and September.

\subsubsection{Uncertainty in drought indices}

The mean areal temperature and precipitation series for the Czech Lands are calculated from the full number of stations used from 1876 (precipitation) and 1883 (temperature) onwards. This means that SPEI-1, Z-index and PDSI series calculated from the complete set of stations run from only 1883 to 2012. Deeper into the past, the number of stations decreases, with concomitant increase of uncertainty for the

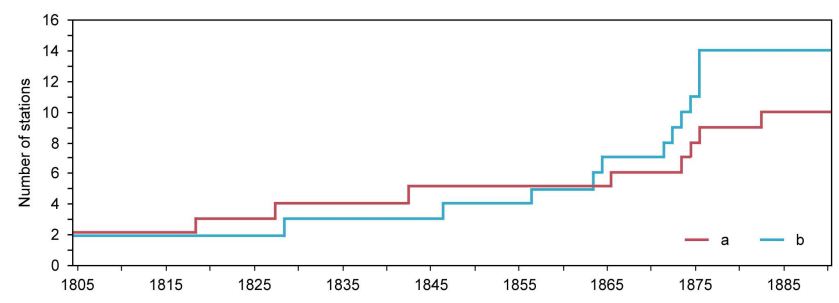

Fig. 8. Number of stations used for calculation of the mean Czech series in 1805-1900: (a) temperature, (b) precipitation.

whole series. High spatial correlations present no problems for temperature, but the great spatial variability typical of precipitation may be an important source of uncertainty. This effect will be more pronounced in SPEI-1 and Z-index than in PDSI. Although the stations used do not vary a great deal in altitude (from $191 \mathrm{~m}$ at Prague-Klementinum to $486 \mathrm{~m}$ in Dačice), the distances between some of them may be more than $200 \mathrm{~km}$. Figure 8 shows changes in the number of stations used for calculation of the mean Czech temperature and precipitation series. Only two stations (Prague-Klementinum and Brno) were used for calculations up to 1818 for temperature and to 1828 for precipitation. The greater increase in the number of stations was achieved as late as in the 1860s1870 s.

\subsubsection{Uncertainty in the territorially limited extension of synoptic situations}

Precipitation totals in the Czech Lands are dependent on the territorial extent of important pressure systems (position of lows, highs, troughs and ridges) and phenomena at subsynoptic and synoptic scales (frontal systems, convection, etc.). The relatively small distances between certain places can also play a significant role. The situation in the Czech Republic in 2012 may serve as an example: severe drought in the eastern part (Moravia and Silesia) and in the western part of Bohemia and above-mean precipitation in Bohemia, particularly the southern part, and also in southern Moravia (Fig. 9a). This spatial distribution reflects summer precipitation totals in particular, which were notably higher in the wetter regions. However, calculation of areal means for the whole Czech Republic smoothes quite significant differences between its various parts (SPEI-15, Z-index $5, \mathrm{PDSI}_{20}$ ).

This uncertainty also has quite important consequences for the evaluation of droughts from documentary data where the available sources come from various parts of the Czech Lands that may be wetter or drier in the corresponding year. Together with the spatial variability mentioned, this can influence interpretation of the precipitation character of individual months, as mentioned in Sect. 5.1.1.

In order better to demonstrate spatial precipitation variability in the Czech Republic, coefficients of variation in homogenised series of April-September precipitation totals 


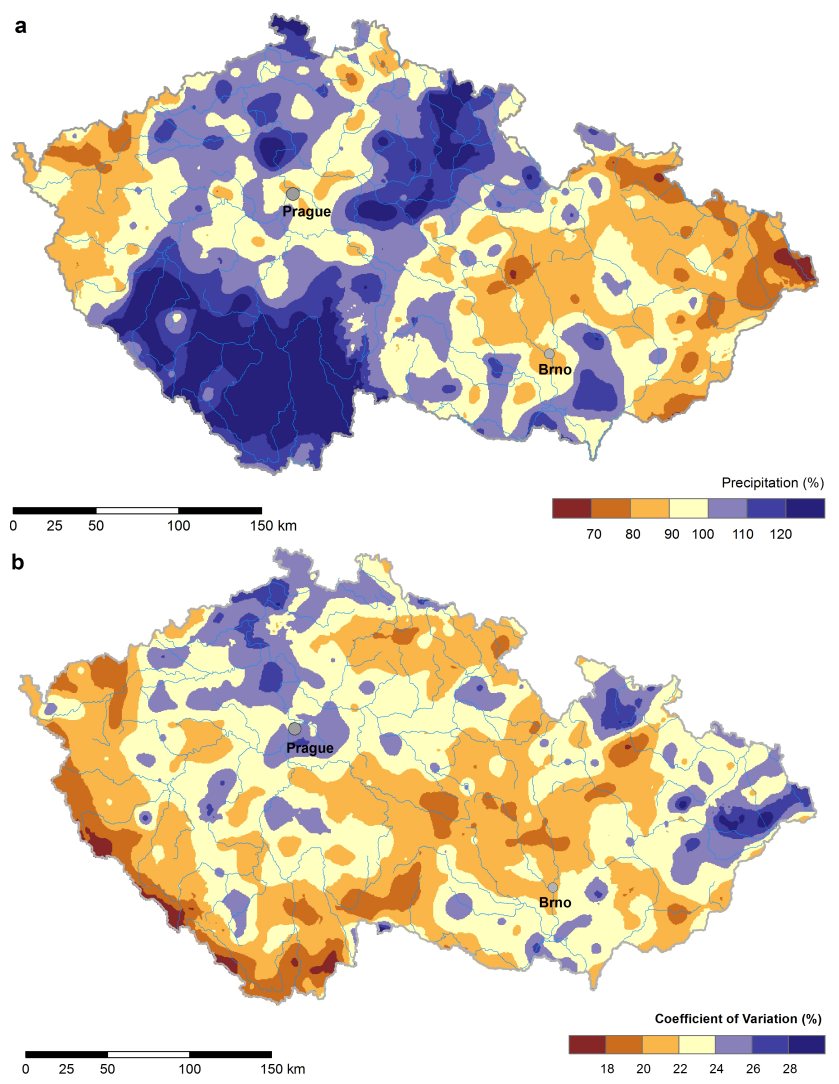

Fig. 9. (a) April-September precipitation totals in the Czech Republic in 2012 expressed as percentages of the 1961-1990 mean show contrasts in totals between the various parts; (b) variability of April-September precipitation totals in the Czech Republic in 1961-2010 expressed by coefficients of variation.

for 787 rain-gauge stations in the 1961-2010 period were calculated (Fig. 9b). These fluctuate between $16.9 \%$ (Nová Pec station) and $31.9 \%$ (Šance). The highest variability is typical of the central parts of Bohemia extending up to the north-west border with Germany, and for a part of southern Moravia stretching further to the north and north-east. While the areas of highest variability in Bohemia tend to be limited to lower positions, they appear mainly in more mountainous locations in the eastern part of the Czech Republic. The generally spotty character of the field may be attributed to the spatially variable character of convective precipitation in the summer half-year.

\subsubsection{Uncertainty in the drought chronology compiled for the Czech Lands}

Merging drought events from both documentary records and instrumental data into one continuous record is obviously not without risk. As mentioned in Sect. 1, identification of meteorological drought is confined almost exclusively to the instrumental period while drought events in the preinstrumental period must more often be defined by deduc- tion from the impacts recorded (on agricultural and forestry produce, the flow of waterways, water levels etc.). This mismatch in drought definitions between both main periods renders it likely that an event of a given objective intensity would not be represented in the same manner were it to occur in both periods. Further, the sensitivity of the landscape (expressed as, for example, crop yields) to droughts, as well as society itself, has changed over past centuries (e.g. Trnka et al., 2012). Thus, even if a drought study could be based on observed impacts it would be difficult to compare drought events of the same intensity over the centuries. On the other hand, the availability of high-quality instrumental data may provide a degree of "over-focus", enabling the depiction of drought episodes that had little or no significant impact, leading to over-reporting of drought in the instrumental period. This was one of the reasons for the decision to use N-year recurrence rather than absolute values of drought index to define a drought period for the purposes of this paper.

However, it is the view of the authors that, even in the light of the limitations above, the importance of drought as a phenomenon justifies compiling this drought chronology of the Czech Lands for 1501-2012 AD. While using documentary evidence to represent drought in the earlier period and instrumental records in later times was dictated by data availability, it still makes good sense. It can be argued that society prior to the 19th century was more vulnerable to drought; general productivity was much lower and considerable dependence on water power made all activity associated with agriculture a very sensitive drought indicator. With the burgeoning of industrialisation from the early 19th century onwards, the sensitivity of agriculture and society to drought inevitably changed and instrumental records provide more objective information about drought. Nonetheless, this chronology has to be taken as a first attempt at establishing a long-term frequency for droughts in the Czech Lands, providing some idea of a longer perspective upon these phenomena.

The way forward towards the compilation of a more complete chronology lies in creating a period in which droughts derived from documentary data overlap with those established by instrumental measurement in form of drought indices. While Czech temperature indices extend to 1854 and have been used for the compilation of a central European temperature series (Dobrovolný et al., 2010), the next focus has to be upon creation of precipitation indices from documentary data. Another promising approach might be found in the quantitative interpretation of the Czech precipitation index series from 1501 and its use for calculation of drought indices into the past.

\subsection{Droughts in the Czech Lands in comparison with tree-ring reconstructions from southern Moravia}

The chronology of droughts in the Czech Lands compiled from documentary evidence may be partly verified by comparison with two existing reconstructions of 


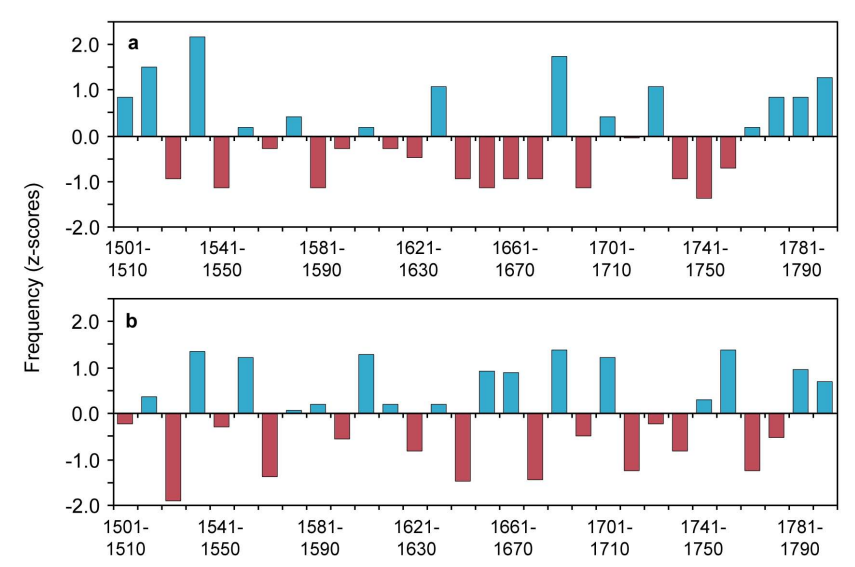

Fig. 10. Decadal frequencies of dry months in the Czech Lands (MAMJJ) (a) and decadal means of MAMJJ precipitation totals reconstructed from TRW in southern Moravia (Brázdil et al., 2002) (b). Both series are expressed as standardised values (z-scores) and values of precipitation totals have been inverted for easier interpretation (positive values in both graphs show more dry periods).

drought/precipitation worked up for southern Moravia from tree-ring widths (TRW). Such a comparison has been made for March-July precipitation totals reconstructed from fir TRW (Brázdil et al., 2002) and for May-June Z-index values derived from the same type of proxy records (Büntgen et al., 2011a). Any direct comparison is complicated by the fact that indices derived from documentary evidence characterise frequency of events relatively well but assessment of the intensity of droughts may be partly biased by the somewhat subjective process of interpreting historical reports. Construction of indices on a seven-degree scale (see Sect. 1) affects records of the true variability (and also intensity) of precipitation/drought events. In contrast, tree-ring reconstructions refer directly to intensity of drought, either through Z-index values or precipitation totals. A further factor that may hamper direct comparison is spatial bias, since series from documentary data relate to the whole territory of the Czech Lands whereas TRW reconstructions to date reflect conditions only in southern Moravia, one of the driest regions in the Czech Republic.

When decadal frequencies of droughts compiled from documentary data (1501-1804) and instrumental record (18052012) in the Czech Lands (Fig. 7) are compared with TRWbased MJ and MAMJJ reconstructions, no coherency is found. Overall correlations are low and non-significant correlations give only 0.22 for MJ Z-index and -0.17 for MAMJJ precipitation. One of the reasons may be that the chronology presented in Fig. 7 summarises annual values, not only the seasons above. Moreover, the instrumental part of the chronology was used in part for the reconstructions and is not fully independent. These are the main reasons for further comparison between only the documentary parts of the Czech drought chronology.
The quantity and quality of documentary data permit direct comparison at the level of decadal values for a period from the start of the 16th century to the end of the 18th century. Because drought frequencies from documentary data are available at monthly resolution, a comparison was made of the numbers of dry months (May-June) with mean Z-index values for the same months in individual decades. This comparison does not indicate any common signal. The overall correlation between numbers of dry months and reconstructed Z-index is not significant $(r=0.25)$ and neither series corresponds in terms of occurrence of the most extreme decades. While the documentary data indicated that the driest decade was 1531-1540, TRW-based Z-index led to the years 16011610. Certain common features were found when frequency of dry months (MAMJJ) was compared with mean reconstructed precipitation totals over the same season for individual decades (Fig. 10). The two data sets were transformed to z-scores for better comparison. In this case, the correlation between the two characteristics of dryness is significant $(r=-0.39)$ and evaluation of dryness from two different sources agrees at least partly for most of the decades. Among the most extremely dry decades to appear are those of 15311540 and 1681-1690 in both data sets. These two characteristics show no long-term trend in drought occurrence but rather a high inter-decadal variability. A tendency towards more dry conditions is typical of both datasets around the end of the 18th century. A lower occurrence of drought in the mid-17th century according to documentary sources is probably related to a smaller quantity of sources (see Sect. 5.1.1).

Similarly, the reconstructed MJ Z-index and MAMJJ precipitation totals may be compared to drought intensity (Fig. 4c) derived from documentary sources for the same seasons. However, comparison with proxy reconstructions shows no significant share of common variability (correlation coefficients reach only 0.12 and 0.34 for MJ and MAMJJ, respectively).

\subsection{Droughts in the Czech Lands in the central European context}

For comparison and for verification of drought occurrence analysis in the Czech Lands on a central European scale, a much higher number of proxy reconstructions of various kinds may be used. These are available at an annual resolution; however, any comparison suffers from inconsistencies arising out of different proxy data and drought characteristics, seasonal emphasis, and various degrees of spatial extent.

The first comparison was made with series of precipitation $(P)$ indices compiled from documentary data for Germany (Glaser, 2008) and Switzerland (Pfister, 1999) because their precipitation/drought characteristics are the most similar to the data used in this study for the pre-instrumental period. Decadal frequencies of droughts in the Czech Lands (Fig. 7) correlate significantly with JJA German $P$ indices $(r=$ -0.43 ) but correlations to annual indices are not significant. 
There are no common features between Czech drought frequencies and Swiss $P$ indices. This result is understandable and consistent with our knowledge of the precipitation/drought regime in the central European region from the instrumental period (see Büntgen et al., 2011a). The territories of Germany and the Czech Lands are adjacent and comprise a far more homogeneous region in terms of circulation characteristics and precipitation regime than more distant Switzerland.

German and Swiss $P$ index series (along with a number of natural proxies) were used in a gridded $(0.5 \times 0.5 \mathrm{deg}$. $)$ multiproxy precipitation reconstruction for Europe by Pauling et al. (2006). A subset of this reconstruction covering central Europe $\left(48^{\circ} \mathrm{N} / 12^{\circ} \mathrm{E}-52^{\circ} \mathrm{N} / 18^{\circ} \mathrm{E}\right)$ was compared with the Czech drought chronology in the common 1501-2000 period at a decadal resolution (Fig. 11). A relatively high and statistically significant correlation was found for JJA values $(r=-0.58)$, implying that the two series share a common variance of about $34 \%$.

Despite very high inter-decadal variability in both series, numerous common features can be found not only for individual decades but also for long-term tendencies (Fig. 11). Less frequent droughts were especially typical of the second half of the 16th century and for the 17th century. Conversely, more frequent droughts occurred in the first part of the 16th century, the end of the 18th century and both series also indicate more droughts during the 20th century. The subset of European precipitation reconstruction (Pauling et al., 2006) can also be used for verification of drought intensity in the Czech Lands. The comparison was made for all JJA seasons with relevant information in historical sources (seasons with missing values were excluded). Altogether, drought intensities from 216 summer seasons in the period 1501-1804 correlate significantly with central European precipitation totals, sharing almost $40 \%$ of common variability. Moreover, these results appear temporally stable; significant correlations were also found in data from individual centuries. Because here comparisons are made between precipitation totals and drought intensity expressed on only an ordinal scale, the results were checked with non-parametric Spearman correlations. These correlations remain significant for individual centuries and, interestingly, the highest Spearman correlation $r_{\mathrm{S}}$ is for the 16th century $\left(r_{\mathrm{S}}=0.74, n=66\right)$. Values for the remaining periods are: 17 th century, $r_{\mathrm{S}}=0.64, n=66$; 18 th century, $r_{\mathrm{S}}=0.38, n=88$. From this analysis it may be concluded that, at the very least, the quality and interpretative value of the documentary sources used in the compilation of Czech drought chronology from $1500 \mathrm{AD}$ are stable and do not change significantly.

The compiled chronology of Czech drought events may be further verified by means of existing dendro-climatological precipitation/drought reconstructions. Such reconstructions refer largely to the late-spring or early-summer moisture regime and cover various parts of central Europe. Only the tree-ring data that is spatially more coherent with the territory of the Czech Lands was employed. Büntgen et al. (2011b) used living and historical fir trees to study hydroclimatic springtime extremes and TRW from their "eastern" regional subset, covering Germany and Czech Lands, and they correlate significantly with frequencies of Czech droughts $(r=-0.36)$ at decadal resolution over the common 1500s-1970s period. Comparable results were also disclosed for drought intensities (Fig. 4c) and the TRW reconstruction in the common period 1501-1804. Overall significant correlation reaches $-0.38(p=0.05)$.

In similar fashion, Czech drought frequency chronology correlates significantly with self-calibrated PDSI reconstructed from pine trees in the Slovak Tatra Mts. (Büntgen et al., 2010) over the common period 1730s-1990s. A relatively high negative correlation $(r=-0.47)$ may be partly related to the higher persistence of PDSI values, since this index better characterises long-term drought events (see Sect. 4.3).

The results of this paper, mainly concerned with the AprilSeptember period, may be complemented by the study by Pauling and Paeth (2007) for winter (DJF) patterns. Dry winters for central and eastern Europe were found more frequently during the 18th century and the second part of the 19th century than for the 1951-2000 period. On the other hand, wet winters have been less frequent in the past three centuries compared to 1951-2000, with the exception of the early 18 th century in central Europe.

\section{Conclusions}

This paper presents an analysis of droughts in the Czech Lands in the AD 1090-2012 period and a unique drought chronology based on documentary and instrumental data (SPEI-1, Z-index, PDSI). The study of droughts over such a long period casts light upon the long-term behaviour of droughts with respect to their frequency, severity, seasonality and impacts, as well as significantly extending knowledge of Czech droughts, analysed previously for 1881-2006 (Brázdil et al., 2009). The current paper does not include dynamic aspects of Czech droughts. Such an analysis for the entire period covered in this study would be very difficult. Moreover, Brázdil et al. (2009) discuss the synoptic climatology of droughts based on changes in the occurrence of daily weather types according the Czech Hydrometeorological Institute classification (Katalog, 1967, 1972) and principal component analysis of sea-level pressure in the AtlanticEuropean area for extreme and severe droughts in 18812006.

Despite great variability since $1501 \mathrm{AD}$, the onset of droughts from the 1990s is especially noteworthy. While the severe droughts of the 19th century, in a relatively cooler climate, were caused by lack of precipitation, the last onset of droughts in the Czech Lands can be more clearly attributed to significantly increasing temperatures than to any important decrease in precipitation totals (Trnka et al., 2011; Brázdil et 


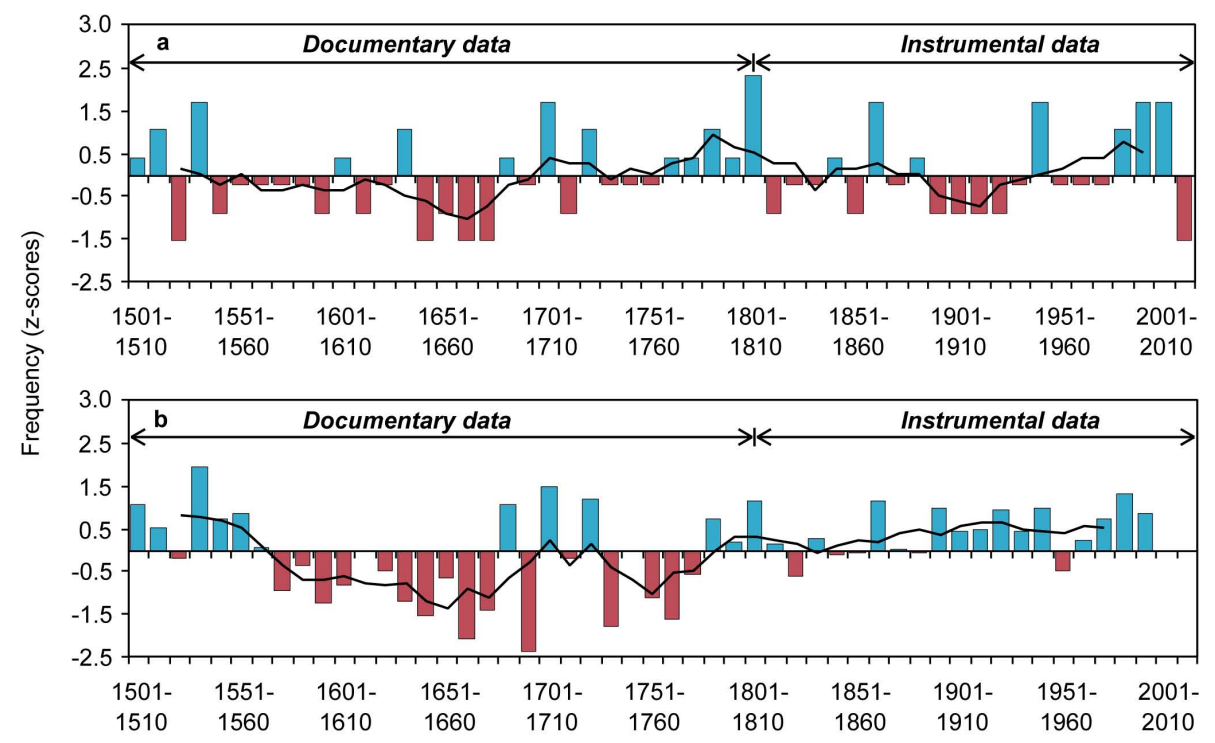

Fig. 11. Decadal frequencies of dry months in the Czech Lands derived from documentary sources and instrumental data (a) and decadal means of reconstructed JJA precipitation totals in central Europe (Pauling et al., 2006) (b) in the period 1501-2000. Both series are expressed as standardised values (z-scores) and values of precipitation totals have been inverted for easier interpretation - more positive values show more dry periods; black lines represent running means for the five terms.

al., 2012a). Knowledge that contributes to modelling for future drought episodes is of particular interest. However, there are signs that agricultural production in the Czech Lands, or at least in parts of them, has grown steadily more sensitive to drought (and increased temperatures) over the past $130 \mathrm{yr}$ (Trnka et al., 2012). Recent studies have also suggested a significant increase in the risk of drought events arising out of climate changes (e.g. Dubrovský et al., 2009; Trnka et al., 2013) when existing projections are realised.

The next improvement in the study of pre-instrumental droughts in the Czech Lands lies in the creation of an overlap period between droughts derived from documentary data and those from the instrumental period. This overlap is also necessary for the quantification of precipitation indices. Such temperature and precipitation series for the Czech Lands would also facilitate calculation of drought indices into the past.

Acknowledgements. The authors would like to acknowledge the financial support of the Grant Agency of the Czech Republic for projects no. P209/11/0956 (R. Brázdil), no. 13-04291S (P. Dobrovolný), no. 13-19831S (L. Řezníčková, H. Valášek, P. Zahradníček) and grant CZ.1.07/2.3.00/20.0248 (M. Trnka, P. Štěpánek). Our thanks to Mr. Tony Long (Svinošice) for the English style corrections.

Edited by: J. Luterbacher

\section{References}

Berger, K.: Geschichte der Stadt Bärn, Deutscher Verein für die Geschichte Mährens und Schlesiens, Verlag des Vereins, Brünn, 320 pp., 1901.

Bradley, R. S.: Paleoclimatology. Reconstructing Climates of the Quaternary, Academic Press, San Diego, London, Boston, New York, Sydney, Tokyo, Toronto, 610 pp., 1999.

Brázdil, R. and Kirchner, K. (Eds.): Vybrané přírodní extrémy a jejich dopady na Moravě a ve Slezsku (Selected Natural Extremes and Their Impacts in Moravia and Silesia), Masarykova univerzita, Český hydrometeorologický ústav, Ústav Geoniky Akademie věd České republiky, v.v.i., Brno, Praha, Ostrava, 432 pp., 2007.

Brázdil, R. and Kotyza, O.: History of Weather and Climate in the Czech Lands I: Period 1000-1500, Zürcher Geographische Schriften 62, Zürich, 260 pp., 1995.

Brázdil, R. and Kotyza, O.: History of Weather and Climate in the Czech Lands IV. Utilisation of Economic Sources for the Study of Climate Fluctuation at Louny and Surroundings in the Fifteenth-Seventeenth Centuries, Masaryk University, Brno, 350 pp., 2000.

Brázdil, R. and Valášek, H.: Počasí v Brně a okolí v letech 17671790 podle záznamů Jana Nepomuka, svobodného pána Hausperského z Fanálu (The weather in Brno in the 1767-1790 period according to records of Jan Nepomuk Hausperský of Fanál), in: Brno v minulosti a dnes, Sborník příspěvků k dějinám a výstavbě Brna XVII, Magistrát města Brna, Archiv města Brna, Brno, 399-443, 2003.

Brázdil, R., Štěpánková, P., Kyncl, T., and Kyncl, J.: Fir treering reconstruction of March-July precipitation in southern Moravia (Czech Republic), 1376-1996, Clim. Res., 20, 223-239, doi:10.3354/cr020223, 2002. 
Brázdil, R., Pfister, C., Wanner, H., von Storch, H., and Luterbacher, J.: Historical climatology in Europe - the state of the art, Clim. Change, 70, 363-430, doi:10.1007/s10584-005-5924-1, 2005.

Brázdil, R., Kundzewicz, Z. W., and Benito, G.: Historical hydrology for studying flood risk in Europe, Hydrol. Sci. J., 51, 739764, doi:10.1623/hysj.51.5.739, 2006a.

Brázdil, R., Valášek, H., and Chromá, K.: Documentary evidence of an economic character as a source for the study of meteorological and hydrological extremes and their impacts on human activities, Geogr. Ann. A, 88, 79-86, doi:10.1111/j.04353676.2006.00285.x, 2006b.

Brázdil, R., Trnka, M., Dobrovolný, P., Chromá, K., Hlavinka, P., and Žalud, Z.: Variability of droughts in the Czech Republic, 1881-2006, Theor. Appl. Climatol., 97, 297-315, doi:10.1007/s00704-008-0065-x, 2009.

Brázdil, R., Dobrovolný, P., Luterbacher, J., Moberg, A., Pfister, C., Wheeler, D., and Zorita, E.: European climate of the past 500 years: new challenges for historical climatology, Clim. Change, 101, 7-40, doi:10.1007/s10584-009-9783-z, 2010.

Brázdil, R., Černušák, T., and Řezníčková, L.: The Weather and Climate in the Region of Olomouc, Czech Republic, Based on Premonstratensian Diaries Kept by the Hradisko Monastery and Svatý Kopeček Priory, 1693-1783, Masaryk University, Brno, 272 pp., 2011.

Brázdil, R., Bělínová, M., Dobrovolný, P., Mikšovský, J., Pišoft, P., Řezníčková, L., Štěpánek, P., Valášek, H., and Zahradníček, P.: Temperature and Precipitation Fluctuations in the Czech Lands During the Instrumental Period, Masaryk University, Brno, 236 pp., 2012a.

Brázdil, R., Chromá, K., Valášek, H., and Dolák, L.: Hydrometeorological extremes derived from taxation records for south-eastern Moravia, Czech Republic, 1751-1900 AD, Clim. Past, 8, 467481, doi:10.5194/cp-8-467-2012, 2012 b.

Brázdil, R., Kundzewicz, Z. W., Benito, G., Demarée, G., Macdonald, N., and Roald, L. A.: Historical floods in Europe in the past millennium, in: Changes in Flood Risk in Europe, edited by: Kundzewicz, Z. W., IAHS Special Publication 10, IAHS Press and CRC Press/Balkema, Wallingford, 121-166, 2012c.

Bretholz, B.: Die Chronik der Böhmen des Cosmas von Prag, Weidmann, MGH SRG NS II, Berlin, 393 pp., 1923.

Büntgen, U., Brázdil, R., Frank, D., and Esper, J.: Three centuries of Slovakian drought dynamics, Clim. Dynam., 35, 315-329, doi:10.1007/s00382-009-0563-2, 2010.

Büntgen, U., Brázdil, R., Dobrovolný, P., Trnka, M., and Kyncl, T.: Five centuries of Southern Moravian drought variations revealed from living and historic tree rings, Theor. Appl. Climatol., 105, 167-180, doi:10.1007/s00704-010-0381-9, 2011a.

Büntgen, U., Brázdil, R., Heussner, K.-U., Hofmann, J., Kontic, R., Kyncl, T., Pfister, C., Chromá, K., and Tegel, W.: Combined dendro-documentary evidence of Central European hydroclimatic springtime extremes over the last millennium, Quaternary Sci. Rev., 30, 3947-3959, doi:10.1016/j.quascirev.2011.10.010, $2011 b$.

Cooper, R. J., Melvin, T. M., Tyers, I., and Wilson, R. J. S.: A tree-ring reconstruction of East Anglian (UK) hydroclimate variability over the last millennium, Clim. Dynam., 40, 1019-1039, doi:10.1007/s00382-012-1328-x, 2013.

Cvrček, J.: Ze starých pamětí města Bzence (From old memoirs of Bzenec town), Časopis Matice moravské, 27, 13-23, 1903.
Čížek, J. J.: Kniha pamětní města Opočna (The memorial book of the town of Opočno), in: Ze starých zápisův. Drobné črty z historie opočenského lidu v 17. a 18. století, 4-17, s.a.

Dai, A.: Characteristics and trends in various forms of the Palmer Drought Severity Index (PDSI) during 1900-2008, J. Geophys. Res., 116, D12115, doi:10.1029/2010JD015541, 2011.

d'Elvert, C.: Chronik der königlichen Stadt Iglau (1402-1617) von Iglauer Stadtschreiber Martin Leupold von Löwenthal, QuellenSchriften zur Geschichte Mährens und Österr.-Schlesiens, 1. Sektion: Chroniken u. dgl., Theil 1., Mährische und schlesische Chroniken, in: Commission der Buchhandlung A. Nitsch, Brünn, 326 pp., 1861.

de Kraker, A. M. J.: Historical climatology, 1950-2006. An overview of a developing science with a focus on the Low Countries, BELGEO, 307-337, 2006.

Dobrovolný, P., Brázdil, R., Valášek, H., Kotyza, O., Macková, J., and Halíčková, M.: A standard paleoclimatological approach to temperature reconstruction in historical climatology: an example from the Czech Republic, A.D. 1718-2007, Int. J. Climatol., 29, 1478-1492, doi:10.1002/joc.1789, 2009.

Dobrovolný, P., Moberg, A., Brázdil, R., Pfister, C., Glaser, R., Wilson, R., van Engelen, A., Limanówka, D., Kiss, A., Halíčková, M., Macková, J., Riemann, D., Luterbacher, J., and Böhm, R.: Monthly, seasonal and annual temperature reconstructions for Central Europe derived from documentary evidence and instrumental records since AD 1500, Clim. Change, 101, 69-107, doi:10.1007/s10584-009-9724-x, 2010.

Dostál, B., Hosák, L., Zemek, M., Zimáková, A., Martinák, M., and Školl, J.: Břeclav - dějiny města (Břeclav - the History of the Town), Musejní spolek v Brně ve spolupráci s Městským národním výborem v Břeclavi, Břeclav, 312 pp., 1968.

Dubrovský, M., Svoboda, M. D., Trnka, M., Hayes, M. J., Wilhite, D. A., Žalud, Z., and Hlavinka, P.: Application of relative drought indices in assessing climate-change impacts on drought conditions in Czechia, Theor. Appl. Climatol., 96, 155-171, doi:10.1007/s00704-008-0020-x, 2009.

Dudík, B.: Olmützer Sammel-Chronik vom Jahre 1432 bis 1656, Schriften der hist. stat. Sektion, Brünn, 61 pp., 1858.

Dvorský, J.: Pražské paměti Jana Piláta Rakovnického z Jenštejna z let 1575-1605 (Prague memoirs of Jan Pilát Rakovnický of Jenštejn from 1575-1605), Pražský sborník historický, 7, 161172, 1972.

Emler, J.: Prameny dějin českých (Sources of Bohemian History). Díl II - Fontes rerum Bohemicarum, Tomus II, Nadání Františka Palackého, Praha, 572 pp., 1874.

Feifalik, J.: Reimchronik eines Iglauer Bürgers aus dem siebenzehnten Jahrhundert (1607-1617), Schriften der historischstatistischen Sektion der k. k. mähr. schles. Gesellschaft des Ackerbaues, der Natur- und Landeskunde, 12, 25-44, 1859.

Fišer, B.: Paměti Hradišťské (Memoirs of Hradiště), Osvěta, Valašské Meziříčí, 157 pp., 1920.

Glaser, R.: Klimageschichte Mitteleuropas. 1200 Jahre Wetter, Klima, Katastrophen, Primus Verlag, Darmstadt, 264 pp., 2008.

Gradl, H.: Die Chroniken der Stadt Eger, Deutsche Chroniken aus Böhmen, Band III, Im Auftrage des Vereins für Geschichte der Deutschen in Böhmen, Prag, 495 pp., 1884.

Heim, R. R.: A review of twentieth-century drought indices used in the United States, B. Am. Meteorol. Soc., 83, 1149-1165, 2002. 
Hlavinka, P., Trnka, M., Semerádová, D., Dubrovský, M., Žalud, Z., and Možný, M.: Effect of drought on yield variability of key crops in Czech Republic, Agr. Forest Meteorol., 149, 431-442, doi:10.1016/j.agrformet.2008.09.004, 2009.

Hrubý, F.: Moravské korespondence a akta z let 1620-1636 (Moravian Correspondence and Files from 1620-1636). Sv. 2. 16251636 (Listy Karla st. z Žerotína 1628-36), Nákladem Země moravskoslezské, Brno, 573 pp., 1937.

Indra, B.: Památky, uschované v báni radn. věže hranické (Memorials kept in the cupola of the town-hall tower in Hranice), Záhorská kronika, 12, 85-88, 1929-1930.

Indra, B. and Turek, A.: Paměti drahotušských kronikářů (Memoirs of the chroniclers of Drahotuše), Časopis vlasteneckého spolku musejního v Olomouci, 55, 219-320, 1946.

Katalog povětrnostních situací pro území ČSSR (The Catalogue of Weather Situations for the CSSR Territory), Hydrometeorologický ústav, Praha, 94 pp., 1967.

Katalog povětrnostních situací pro území ČSSR (The Catalogue of Weather Situations for the CSSR Territory), Hydrometeorologický ústav, Praha, 38 pp., 1972.

Kiss, A.: Historical climatology in Hungary: role of documentary evidence in the study of past climates and hydrometeorological extremes, Idöjárás, 113, 315-339, 2009.

Klemm, F.: Die Entwicklung der meteorologischen Beobachtungen in Österreich einschliesslich Böhmen und Mähren bis zum Jahr 1700, Annalen der Meteorologie (NF), 21, Offenbach am Main, 48 pp., 1983.

Kolár, J.: Marek Bydžovský z Florentina, Svět za tří českých králů. Výbor z kronikářských zápisů o letech 1526-1596 (Marek Bydžovský of Florentinum. The World in the Reign of Three Czech Kings. Selection from chronicle records for the years of 1526-1596), Svoboda, Praha, 296 pp., 1987.

Lauscher, F.: Beiträge zur Wetterchronik seit dem Mittelalter, Sitzungsberichte der mathem.-naturw. K1., Abt. II, 194, 93-131, 1985.

Lechner, K.: Zur Geschichte der Preise, Notizenblatt des Vereines für die Geschichte Mährens and Schlesiens, 151-152, 1896.

Mareš, F.: Kronika Budějovská (The České Budějovice Chronicle), Věstník Královské české společnosti nauk za r. 1920, Praha, 96 pp., 1922.

Mauelshagen, F.: Klimageschichte der Neuzeit 1500-1900, Wissenschaftliche Buchgesellschaft, Darmstadt, 144 pp., 2010.

McKee, T. B., Doesken, N. J., and Kleist, J.: The relationship of drought frequency and duration to time steps, in: Preprints, 8th Conference on Applied Climatology, Anaheim, 17-22 January, 179-184, 1993.

Ondrůj, A.: Dokument ze života na žerotínské tvrzi v Židlochovicích na přelomu 16. a 17. století (Document from the life in the Žerotín's citadel in Židlochovice at the turn of the 16th and 17th century), Jižní Morava, 13, 168-177, 1977.

Palacký, F.: Staří letopisové čeští od roku 1378 do 1527 čili pokračování v kronikách Přibíka Pulkavy a Beneše z Hořovic z rukopisů starých vydané (Old Bohemian Annals from 1378 to 1527 , or the Continuation in Chronicles by Přibík Pulkava and Beneš of Hořovice Published from Old Manuscripts), in: Charvát, J.: Dílo Františka Palackého, Svazek druhý, Nakladatelství L. Mazáč, Praha, 472 pp., 1941.

Palme, A.: Warnsdorf mit seinem historischen Denkwürdigkeiten von wessen Gründung an bis zum Jahre 1850, J. Hamann, B.
Leipa, 255 pp., 1913.

Palmer, W. C.: Meteorological Drought, Office of Climatology Research Paper 45, US Weather Bureau, Washington, 58 pp., 1965.

Pauling, A. and Paeth, H.: On the variability of return periods of European winter precipitation extremes over the last three centuries, Clim. Past, 3, 65-76, doi:10.5194/cp-3-65-2007, 2007.

Pauling, A., Luterbacher, J., Casty, C., and Wanner, H.: Five hundred years of gridded high-resolution precipitation reconstructions over Europe and the connection to large-scale circulation, Clim. Dynam., 26, 387-405, doi:10.1007/s00382-005-0090-8, 2006.

Peřinka, F. V.: Znojemský okres (The Znojmo District), Vlastivěda moravská, II. Místopis Moravy 76, Musejní spolek Brno, 551 pp., 1904.

Peters, J.: Václav Kněžoveský a jeho paměti (Václav Kněžoveský and his memoirs), Slánský obzor - Ročenka Musejního spolku ve Slaném, 6, 13-56, 1898.

Peters, K.: Dějiny jezuitské koleje $\mathrm{v}$ Klatovech (The history of the Jesuit college in Klatovy), Časopis společnosti přatel starožitností, 41-43, 214-248, 1946.

Pfister, C.: Wetternachhersage. 500 Jahre Klimavariationen und Naturkatastrophen (1496-1995), Verlag Paul Haupt, Bern, Stuttgart, Wien, 304 pp., 1999.

Pfister, C.: Klimawandel in der Geschichte Europas. Zur Entwicklung und zum Potenzial der historischen Klimatologie, Österreichische Zeitschrift für Geschichtswissenschaften, 12, 743, 2001.

Pfister, C., Weingartner, R., and Luterbacher, J.: Hydrological winter droughts over the last 450 years in the Upper Rhine basin: a methodological approach, Hydrol. Sci. J., 51, 966-985, doi:10.1623/hysj.51.5.966, 2006.

Richter, E.: Königswald in älterer Zeit, Beiträge zur Heimatskunde des Elbetales, 2, 171-181, 1940.

Rojecki, A., Girgus, R., and Strupczewski, W.: Wyjatki ze zródel historycznych o nadzwycajnych zjawiskach hydrologicznometeorologicznych na zemiach polskich w wiekach od $\mathrm{X}$ do XVI, Wydawnictwa Komunikaciji i Lacznosci, Warszawa, 214 pp., 1965.

Schlesinger, L.: Simon Hüttels Chronik der Stadt Trautenau (14841601), Deutsche Chroniken aus Böhmen, Band II, Im Auftrage des Vereins für Geschichte der Deutschen in Böhmen, Prag, 438 pp., 1881.

Schreiber, V.: Zápisník Houserů z České Skalice (The Houser's notepad from Česká Skalice), Hradecký kraj, 6, 51-53, 1909.

Strnad, J.: M. Šimona Plachého z Třebnice Paměti Plzeňské (Memoirs of Plzeň by M. Šimon Plachý of Třebnice), Publikací Spolku přátel vědy a literatury české v Plzni 4, 245 pp., 1883.

Strnadel, B.: Nejstarší kronika města Frenštátu pod Radhoštěm (The Oldest Chronicle of Frenštát pod Radhoštěm Town), Nakladatelství krajského národního výboru v Ostravě, Ostrava, 52 pp., 1950.

Strömmer, E.: Klima-Geschichte. Methoden der Rekonstruktion und historische Perspektive Ostösterreich 1700 bis 1830, Franz Deuticke, Wien, 325 pp., 2003.

Šůla, J.: Počasí v Orlických horách před 400 lety (The weather in the Orlické hory Mts. before 400 years), Listy Orlického muzea, 2, 281-285, 1967.

Thornthwaite, C. W.: An approach towards a rational classification of climate, The Geographical Review, 38, 55-94, 1948. 
Tiray, J.: Paměti. Z Praskoles u Telče (Memoirs. From Praskolesy at Telč), Selský archiv, 6, 138-142, 1907.

Trnka, M., Brázdil, R., Dubrovský, M., Semerádová, D., Štěpánek, P., Dobrovolný, P., Možný, M., Eitzinger, J., Málek, J., Formayer, H., Balek, J., and Žalud, Z.: A 200-year climate record in Central Europe: implications for agriculture, Agron. Sustain. Dev., 31, 631-641, doi:10.1007/s13593-011-0038-9, 2011.

Trnka, M., Brázdil, R., Olesen, J. E., Eitzinger, J., Zahradníček, P., Kocmánková, E., Dobrovolný, P., Štěpánek, P., Možný, M., Bartošová, L., Hlavinka, P., Semerádová, D., Valášek, H., Havlíček, M., Horáková, V., Fischer, M., and Žalud, Z.: Could the changes in regional crop yields be a pointer of climatic change?, Agr. Forest Meteorol., 166-167, 62-71, doi:10.1016/j.agrformet.2012.05.020, 2012.

Trnka, M., Dubrovský, M., Svoboda, M. D., Semerádová, D., Gates, M. J., Žalud, Z., and Wilhite, D. A.: Developing a regional drought climatology for the Czech Republic, Int. J. Climatol., 29, 863-883, doi:10.1002/joc.1745, 2009.

Trnka, M., Kersebaum, K. C., Eitzinger, J., Hayes, M., Hlavinka, P., Svoboda, M., Dubrovský, D., Semerádová, D., Wardlow, B., Pokorný, E., Možný, M., Wilhite, D. A., and Žalud, Z.: Consequences of climate change for the soil climate in the Central Europe and the Central plains of the United States, Clim. Change, in review, 2013.

Tutsch, F.: Die älteste Chronik Römerstadts und ihr Verfasser, in: XVI. Jahresbericht der Landesoberrealschule zu Römerstadt, Römerstadt, 4-47, 1914.

van der Schrier, G., Briffa, K. R., Jones, P. D., and Osborn, T. J.: Summer moisture variability across Europe, J. Climate, 19, 2818-2834, doi:10.1175/JCLI3734.1, 2006.

Vicente-Serrano, S. M., Beguería, S., and López-Moreno, J. I.: A multi-scalar drought index sensitive to global warming: The Standardized Precipitation Evapotranspiration Index - SPEI, J. Climate, 23, 1696-1718, doi:10.1175/2009JCLI2909.1, 2010.

Vicente-Serrano, S. M., Beguería, S., López-Moreno, J. I., Angulo, M., and El Kenawy, A.: A global $0.5^{\circ}$ gridded dataset (19012006) of a multiscalar drought index considering the joint effects of precipitation and temperature, J. Hydrometeorol., 11, 10331043, doi:10.1175/2010JHM1224.1, 2011.

Wetter, O. and Pfister, C.: An underestimated record breaking event - why summer 1540 was likely warmer than 2003, Clim. Past, 9, 41-56, doi:10.5194/cp-9-41-2013, 2013.

Wetter, O., Pfister, C., Luterbacher, J., Werner, J., Wagner, S., Zorita, E., Büntgen, U., Siegfried, W., Glaser, R., Riemann, D., Himmelsbach, I., Contino, A., Burmeister, K. H., Litzenburger, L., Barriendos, M., Brázdil, R., Kiss, A., Camenisch, C., Limanowka, D., Pribyl, K., Labbé, T., Retsö, D., Bieber, U., Rohr, C., Spring, L., Nordli, O., Soderberg, J., and Alcoforado, M.: The European Mega-drought of 1540 - an evidence based Worst Case Scenario, Clim. Change, in preparation, 2013.

Wilson, R. J. S., Luckman, B. H., and Esper, J.: A 500 year dendroclimatic reconstruction of spring-summer precipitation from the lower Bavarian Forest region, Germany, Int. J. Climatol., 25, 611-630, doi:10.1002/joc.1150, 2005.
Wilson, R., Miles, D., Loader, N. J., Melvin, T., Cunningham, L., Cooper, R., and Briffa, K.: A millennial long March-July precipitation reconstruction for southern-central England, Clim. Dynam., 40, 997-1017, doi:10.1007/s00382-012-1318-z, 2013.

Winter, Z.: O životě na vysokých školách pražských knihy dvoje. Kulturní obraz XV. a XVI. století (Two books of the life at the high schools in Prague. Cultural picture of the 15th and 16th centuries), Nákladem Matice České a jubilejního fondu Král. české společnosti nauk, Praha, 614 pp., 1899.

Wolkan, R.: Eine unbekannte Chronik von Joachimsthal, Erzgebirgszeitung, 11, 11-13, 37-39, 84-86 and 222-224, 1890.

Zemek, P.: Bartoškova kronika (The Bartošek Chronicle), Muzeum J. A. Komenského v Uherském Brodě v nakladatelství Tomáš Ježek - Otobre 12, Uherské Hradiště, 336 pp., 2004.

\section{Archival sources}

(S1) Městská knihovna Praha, sign. 35 D 19: O hrozném a velikém suchu zdržení deštu a odtud následujícím nedostatku vody, jakéhož sucha žádný z lidí nynějších, ode sta let i výšeji, starých nepamatuje. Kázání učiněné v kostele domaželitském (sic!). Nyní pak kvůli pobožných křesťanů k probuzení lidu Božího, k horlivému pokání a modlitbám svatým vůbec vydané. Odemne (sic!) kněze Daniele staršího Philomatesa, služebníka Slova Páně v Domaželicích (sic!), Notariusa Řádu kněžstva Páně evangelitského v podkraji (sic!) Holomouckém. Vytištěno v Holomoucí (sic!) u Jiř́̌ka Handle. Léta Páně 1616.

(S2) Regionální muzeum Litoměřice, inv. č. SV H 14142: Daniel Adam z Veleslavína, Kalendář Historický. To jest krátké poznamenání všech dnuov jednoho každého měsíce přes celý rok. $\mathrm{K}$ nim přidány jsou některé paměti hodné Historiae o rozličných příhodách a proměnách, jak národuov jiných a zemí v Světě, tak také a obzvláštně národu i Království Českého z hodnověrných Kronik. S pilnosti sebráno, vytištěno a vydáno prací a nákladem M. Daniele Adama z Veleslavína. Vytlačeno v Starém Městě Pražském. Leta posledního věku: MDXC (1590).

(S3) SOkA Česká Lípa, Sbírka rukopisů, karton č. 3: Meisters Hans Kriesches Chronik der Stadt Böhmisch-Leippa bis zum Jahre 1621 [1171-1621]. Ed. Bienert, 239 pp., s.d.

(S4) SOkA Louny, fond AM Louny - kroniky, sign. Ch 1: Chronica civitatis Launensis in Boemia Auctore Paulo Mikssowicz servo consulari.

(S5) SOkA Litoměřice, fond AM Litoměřice, sign. IV B 1a: Kniha pamětní litoměřických městských písařů 1570-1607.

(S6) SOkA Teplice, fond AM Krupka, dodatky inv. č. 1: Knott, R.: Michel Stüelers Gedenkbuch.

(S7) Zámek Nelahozeves, RLK, sign. VI Ef 26: Raudnitzer Denkwürdigkeiten vom J[ahre] 1718 bis 1781 aus dem Tagebuche einer Raudnitzer Bür[ger] Wen[zels] Nik[olaus] Brodsky abgeschrieben.

(S8) Zemský archiv Opava - pobočka Olomouc, Sbírka rukopisů Metropolitní kapituly Olomouc, CO 632: Diarium piaristické koleje Stará Voda z let 1690-1718. 